\title{
Śląsk Cieszyński: spojrzenie na regionalizm z perspektywy geografii społecznej
}

\begin{abstract}
The multidimensionality and multifacetedness of relations between residents and the area they inhabit in the form of regionalism, as well as the activities of organizations aimed at the development of pro-regional attitudes have found themselves in the field of interest of various scholarly disciplines, including geography. Roman Matykowski's aim in this article is to examine this phenomenon from the perspective of geography, which in various periods of its development also used the achievements of other disciplines (e.g., sociology). In the second part his article, Matykowski uses the perspective of social geography to present selected results of his research on the specific regionalism in Cieszyn Silesia.
\end{abstract}

Key words: regionalism, identity, regionalism syndromes, Cieszyn Silesia

\section{Wstęp}

Tradycyjne definicje regionalizmu interpretują go jako przejaw rodzaju świadomości społecznej, funkcjonującej wśród mieszkańców określonego terytorium i wytworzone między tymi mieszkańcami więzi społeczne, ale też jako ukształtowany stan swoistych cech kultury na terytorium, które służą do zaznaczania odrębności regionalno-etnicznej obszaru oraz prowadzą do utrwalania i pogłębiania tożsamości (Kwiatkowski, 1984; Damrosz, 1987; Chojnicki, Czyż, 1992). Z kolei świadomość regionalna — według Zbigniewa Rykla — stanowi część świadomości społecznej, która odnosi się do poczucia odrębności własnego regionu lub własnej grupy regionalnej (Rykiel, 1985). Często w warunkach polskich wskazuje się na 
związki świadomości regionalnej z innymi segmentami świadomości społecznej, takimi jak świadomość historyczna i tożsamość kulturowa.

Wśród źródeł współczesnego regionalizmu w Polsce w opracowaniach z różnych dyscyplin naukowych wymienia się średniowieczne podziały okresu rozbicia dzielnicowego po śmierci Bolesława Krzywoustego w 1138 roku czy też 150-letni podział ziem polskich w okresie zaborów (zob. Sowa, 2000; Szczepański, ŚlęzakTazbir, 2008). W wymiarze geograficznym pojawiło się szereg dość uproszczonych modeli struktury regionalnej Polski, jednak bez jasnych kryteriów tego podziału. Do takich podziałów terytorium współczesnej Polski można zaliczyć podział kraju na siedem regionów geograficznych Michała Janiszewskiego, bazujący na koncepcji naturalnej spójności komunikacyjnej (wyznaczonej na podstawie głównych szlaków wodnych - sieci hydrograficznej) (Janiszewski, 1959). W oparciu o kryteria historyczno-hydrograficzne na dziewięć (lub nawet dziesięć, przy podziale Śląska na dwie części) regionów podzielił Polskę Andrzej Piskozub (Piskozub, 2002). Z kolei Rykiel wyróżnił pięć regionów zakorzenionych w historii dzielnicowej, ale trzy inne regiony w tym podziale kraju (katowicki, łódzki i bydgoski) wynurzyły się w wyniku XIX-wiecznego procesu uprzemysłowienia (Rykiel, 1999). W oparciu o swoiste podłoże historyczne, w którym zachowały się pewne ślady kultury materialnej, wzorce życia, ale też i nazwy, sześć regionów kraju wydzielił Bohdan Jałowiecki, określając je mianem regionów reliktowych (Jałowiecki, 1996). Należy zwrócić uwagę, że podobne podziały Polski na duże regiony geograficzne wykorzystywane są w procesie edukacji szkolnej i stają się wyraźnym konstruktem poznawczym wielu mieszkańców regionów (zob. Dylikowa, 1973; Kiełczewska-Zaleska, 1980). Zwolennicy stosowania takich podziałów regionalnych w edukacji traktują takie regiony geograficzno-historyczne jako twory trwałe.

Innym wzorcem struktury regionalnej kraju opierającym się na podłożu historycznym był układ dzielnicowy — przez Rykla określony mianem stref cywilizacyjnych (Rykiel, 1993; 2000). Wyróżnił on cztery takie strefy: porosyjską, poaustriacką i popruską (wynikające z podziału zaborowego ziem polskich) oraz odzyskaną (terytoriów przyłączonych do Polski po 1945 roku). Większą złożoność historyczną terytoriów zaliczanych do dawnych zaborów (struktur administracyjnych państw zaborowych) dostrzegał Mariusz Kowalski, który wyróżnił m.in. Galicję i Śląsk Cieszyński, ale ten drugi włączył do Górnego Śląska (Kowalski, 2003).

Wzrost zainteresowania regionalizmem nastąpił w okresie transformacji ustrojowej i społeczno-ekonomicznej kraju na przełomie lat 80. i 90. XX wieku. Wówczas to podjęto m.in. dyskusję o przebudowie struktury administracyjno-terytorialnej Polski; wśród projektów tej struktury znalazły się koncepcje utworzenia dużych jednostek terytorialnych o szerokich kompetencjach samorządowych, a nawet autonomicznych, nazywanych regionami. Poza tym pojawiły się również postulaty przywrócenia pośredniego szczebla administracyjnego — powiatów — przy czym wielkość tych jednostek subregionalnych miała nawiązywać do wielkości powiatów sprzed 1975 roku, choć mogły być od nich zarówno mniejsze, jak i większe 56 terytorialnie. 
Drugą kategorią regionalizmu, którą poddano badaniom szczególnie w krajach Zachodu (w tym w świecie anglosaskim), był tzw. regionalizm kreatywny, nazywany również podmiotowym, który interpretuje się jako zespół działań gospodarczych, kulturalnych i politycznych zbiorowości terytorialnej, mających na celu zarówno obronę jej interesów (w tym modernizację gospodarki), jak i zachowanie jej odrębności (wartości zagrożonych) m.in. przez władze centralne państwa (zob. Chojnicki, Czyż, 1992; Skorowski, 1999; Matykowski, 2003). Od przełomu wieków zakres tych działań bywa coraz bardziej poszerzany w stronę sfery działań ekonomicznych, planistycznych strategii regionalnych czy marketingu terytorialnego (zob. Bradshaw, 1988; Keating, 1998; Deas, 2000). Stąd ważną rolę odgrywają promotorzy działań prorozwojowych regionu, do których zalicza się m.in. ekspertów w dziedzinie polityki publicznej, naukowców, liderów organizacji pozarządowych i działaczy samorządowych. W ocenie Anny Gąsior-Niemiec ta postać tzw. nowego regionalizmu wypiera starą postać regionalizmu reprezentowaną przez zbiorowość terytorialną bazującą na opartej na podzielanych „wartościach i zakotwiczonej w terytorialnych lojalnościach politycznych" (Gąsior-Niemiec, 2010, s. 42). Nowy regionalizm wyraża się m.in. poprzez ,pełną »otwartość« systemów regionalnych, ich »płynność« i »elastyczność« oraz »zawieszenie« w sieciach wieloszczeblowych [...] transnarodowych i globalnych przepływów" (Gąsior-Niemiec, 2010, s. 43).

W latach 90. podjęto w Polsce z większą intensywnością studia obejmujące problematykę zarówno regionu, jak i ukształtowanego w nim regionalizmu, które znalazły się w polu badawczym różnych dyscyplin naukowych. Oczywiste stało się duże zainteresowanie tą problematyką w dziedzinie socjologii, gdyż w tym przypadku pewną inspiracją było studium Stanisława Ossowskiego (Ossowski, 1947). Należy zwrócić uwagę, że opracowania dotyczące regionu, regionalizmu i tożsamości regionalnej skupiały się często na dorobku własnej dyscypliny, a pomijały zazwyczaj dorobek innych dyscyplin lub dokonywały celowej selekcji takich opracowań. Czasem podejmowano próbę określenia pewnych wspólnych płaszczyzn analizy regionu i regionalizmu, co było sprowadzane do takich zagadnień, jak: 1) tworzenie i kształtowanie więzi społecznych w regionie (przejawiające się m.in. w rozwoju świadomości i tożsamości regionalnej oraz budowaniu w oparciu o nie ideologii regionalnej); 2) wieloaspektowe działania społeczno-polityczne, kulturowe i ekonomiczne mieszkańców, współcześnie sprowadzane do działań aktorów (lub graczy) regionalnych, mające na celu krystalizację i promowanie regionu; 3) funkcjonowanie regionu jako nośnika wartości kultury i dążenie do zachowania odrębności w tym zakresie. Realizacja wyzwań związanych z tak różnymi spojrzeniami na region i regionalizm znalazła odzwierciedlenie m.in. w poświęconej tym zagadnieniom publikacji Region, regionalizm - pojęcia i rzeczywistość pod redakcją Kwiryny Handke (1993) oraz w wydaniu w Katowicach kilku numerów serii „Regiony Polski” (od 2000 roku). Następna faza realizacji takich wyzwań powinna odbywać się w ramach podejścia inter- i transdyscyplinarnego w tej dziedzinie.

Niniejsze opracowanie ma dwa równorzędne cele. Pierwszym z nich jest omówienie sytuacji problemowej i konceptualizacji studiów nad regionalizmem 
polskim z perspektywy geografii społecznej, a drugim — przedstawienie niektórych wyników badań empirycznych nad specyficznym regionalizmem na Śląsku Cieszyńskim.

Spojrzenie geograficzne na regionalizm w Polsce ulegało zmianom $w$ trakcie rozwoju tej dyscypliny naukowej w XX wieku. W związku z tym, że geografię traktowano jako naukę przyrodniczą (ze słabą sferą zainteresowań składnikiem społecznym środowiska), regionalizm wiązano z ruchem zmierzającym do wyróżnienia obszarów (krain) na podstawie odrębności przyrodniczej (zob. Pawłowski, 1934). Wykorzystanie koncepcji regionalistycznej opartej na odrębności przyrodniczej, ale i dziedzictwa kulturowego znalazły też zwolenników w ruchu krajoznawczym okresu międzywojennego. Wraz z rozwojem geografii społeczno-ekonomicznej (zwanej też geografią człowieka) w systemie nauk geograficznych coraz częściej zaczęto czerpać z doświadczeń badawczych i składnika teoretycznego innych nauk społecznych. W końcu doprowadziło to do formalnej separacji obu części składowych tradycyjnie rozumianej geografii ${ }^{1}$. Innym zjawiskiem komplikującym perspektywę geograficzną w podejściu do regionalizmu jest proces ciągłego tworzenia wąskich subdyscyplin na gruncie zarówno geografii fizycznej, jak i geografii człowieka. Jedną z takich subdyscyplin jest geografia społeczna. Jednakże pozycja geografii społecznej w mozaikowatej strukturze subdyscyplin geografii była i jest dość specyficzna. W latach 70. XX wieku Stefan Golachowski postulował, by geografia społeczna była jedną z trzech podstawowych subdyscyplin geografii, obok geografii fizycznej i geografii ekonomicznej, ale ta propozycja się nie przyjęła (Golachowski, 1975). Współcześnie w Polsce geografię społeczną traktuje się różnorodnie: od sposobu (formy) wykorzystania technik zbierania danych z nauk społecznych - poprzez luźno powiązane problemy społeczne tradycyjnych subdyscyplin geografii człowieka (np. społeczna geografia transportu, społeczna geografia przemysłu, czyli geografia społeczna jako zlepieniec), dalej poprzez wyraźnie zdefiniowaną subdyscyplinę geografii człowieka, co prawda o zmieniającej się problematyce badawczej (do której zalicza się również badania świadomości i tożsamości regionalnej) — po różne postaci podejść do badań rzeczywistości (interpretacje humanistyczne, strukturalistyczne itp.). Istotny wpływ na społeczno-geograficzne wzorce badań nad regionalizmem, a zwłaszcza świadomością regionalną mieszkańców województwa katowickiego, miały prace Rykla (Rykiel, 1985; 1989a; 1989b). $\mathrm{Na}$ Śląsk Cieszyński często spogląda się przez pryzmat dziejów historycznych, a szczególnie wyidealizowanym obrazem przestrzennym tego regionu jest zasięg tego obszaru z lat 1850 - 1918. Stąd też regionalizm Śląska Cieszyńskiego zalicza się do kategorii paleoregionalizmu reliktowego, opartego na podłożu historycznym i odwołującego się do pamięci historycznej, a odnoszącego do skali wielkościowej subregionu (tj. niedużego obszaru) (zob. Prawelska-Skrzypek, Matykowski, 2001; Studnicki, 2015). Podejmuje się również poszukiwania nowych form regionalizmu na tym terenie w oparciu o współpracę w ramach regionu przygranicznego czy

${ }^{1}$ Zob. Rozporządzenie Ministra Nauki i Szkolnictwa Wyższego z dnia 20 września 2018 r. w sprawie dziedzin nauki i dyscyplin naukowych oraz dyscyplin artystycznych. Dz.U. 2018, poz. 1818. 
też jednostek terytorialno-administracyjnych (zob. Kłosowski, Runge, 2001; Runge, 2003).

\section{Regionalizm w Polsce XX wieku}

Po odrodzeniu Polski w latach 1918 - 1921 z jednej strony władze państwowe, podejmując zabiegi scalenia w jedną całość terytoriów będących pod kontrolą Rosji, Austro-Węgier i Niemiec (Prus), patrzyły podejrzliwie na tendencje regionalistyczne, upatrując w nich możliwość rozwoju separatyzmu. Co prawda Polska zobowiązała się — podpisując konwencję międzynarodową w Genewie w 1922 roku — nadać autonomię województwu śląskiemu, ale na obszarach o charakterze wielokulturowym (i wieloetnicznym) przyjmowano, że to kultura polska jest istotnym nośnikiem cywilizacyjnym i tożsamościowym. Jednakże z drugiej strony pojawiło się dość specyficzne zainteresowanie popularyzacją postaw regionalistycznych w edukacji szkolnej, którą zajęły się Polskie Towarzystwo Krajoznawcze oraz Związek Nauczycielstwa Szkół Powszechnych (zob. Kwiatkowski, 1984; Sługocki, 1990). W tym drugim przypadku za regionalizm uznano - popularyzowane m.in. poprzez nauczycieli (w tym historii i geografii) oraz krajoznawców — formy przywiązania do własnej ,ziemi” i pozytywnej oceny jej walorów. W tym sensie ,ziemia” była na ogół pojmowana jako nieduży region, zbliżony wielkością terytorialną do ówczesnych powiatów lub zespołu powiatów, a takie związki emocjonalne nie zagrażały tendencjom separatystycznym.

Z kolei po II wojnie światowej Polska w nowym kształcie terytorialnym stała się państwem wyraźnie jednolitym narodowo, a nowy system władzy politycznej, budując specyficzną formę socjalizmu, odrzucał idee i przejawy regionalizmu jako „przeżytki kapitalizmu”. Pewien dyskurs o roli i funkcjach regionalizmu w Polsce Ludowej rozpoczął się dopiero na początku lat 60. Jednym z niewielu empirycznych rozpoznań tego zjawiska była ankieta miesięcznika popularyzującego geografię „Poznaj Świat” przeprowadzona wiosną 1963 roku wśród czytelników tego czasopisma. Wyniki tej ankiety przedstawił Stanisław Berezowski, zaznaczając, że znaczna większość ankietowanych (76\%) określiła swoją tożsamość regionalną, odwołując się do tradycyjnego podziału Polski na regiony geograficzno-historyczne (Berezowski, 1963). Większość z tych regionów identyfikowanych przez badanych czytelników odnosiła się do jednostek dużych, takich jak Śląsk, Wielkopolska czy Mazowsze, ale pojawiły się też odwołania do regionów znacznie mniejszych, w tym do Śląska Cieszyńskiego.

W maju 1975 roku przeprowadzono dość błyskawicznie zmianę podziału administracyjnego, w wyniku której zlikwidowano jednostki pośrednie o wielowiekowej tradycji — powiaty oraz dotychczasowe duże województwa — zastępując je względnie małymi 49 nowymi województwami. Tak więc obok 17 miast pełniących wcześniej funkcję siedziby województw 32 miasta awansowały na siedziby nowo 
utworzonych województw. W niektórych z tych ośrodków zaczęto kształtować przy pomocy władz partyjnych i mediów - nowe postawy i aspiracje regionalne związane ze strukturą administracyjną. Przykładem takich działań były przedsięwzięcia podejmowane przez władze administracyjno-polityczne województwa bielskiego, które zaczęły kształtować m.in. poprzez środki masowego przekazu postawy regionalistyczne tak, by w świadomości mieszkańców województwa pojawił się nowy twór regionalny — Podbeskidzie. Należy zaznaczyć, że gdy w 1998 roku w Sejmie uchwalano ustawę o nowym podziale administracyjnym Polski, niektórzy parlamentarzyści z Podbeskidzia nie podporządkowali się dyscyplinie partyjnej i występowali za zachowaniem tej jednostki w nowej strukturze administracyjnej (np. Grażyna Staniszewska). W okresie niemal ćwierćwiekowego funkcjonowania tych mniejszych województw rzadko podejmowano działania mające na celu budowanie silniejszych więzi emocjonalnych z nowym regionem administracyjnym (nadając mu też nazwę własną). Pod koniec istnienia tych 32 ośrodków wojewódzkich „z awansu” można zauważyć, że wytworzone postawy regionalistyczne były słabe, a jedynym często pozornym przejawem regionalizmu było określane mianem regionocentryzmu (zob. Matykowski, 2006) dążenie do zachowania ważnych funkcji administracyjnych w ośrodku, zazwyczaj w interesie graczy regionalnych w nim skupionych.

Propozycje do powrotu dużych regionów pełniących funkcję województw pojawiały się w latach 80 ., a jednym z promotorów tej koncepcji było Zrzeszenie Pomorsko-Kaszubskie, podejmujące dyskusję na temat roli współczesnego regionalizmu w przemianach kraju na łamach swojego czasopisma „Pomerania”. W początkowym okresie przekształceń ustrojowych, na początku lat 90 . dołączyły do Zrzeszenia inne ruchy regionalne, takie jak Unia Wielkopolan, Ruch Autonomii Śląska czy Związek Górnośląski. W wyniku konsolidacji różnych organizacji proregionalnych powstało ogólnopolskie porozumienie tych ruchów w postaci Ligi Regionów, które działało na rzecz wprowadzenia dużych terytorialnie regionów (województw). Jednakże w drugiej połowie lat 90. organizacje te zostały zmarginalizowane przez partie polityczne.

\section{Sytuacja problemowa i konceptualizacja badań}

Wydaje się dość oczywiste, że pojęcie regionalizmu jest nierozłącznie związane z koncepcją regionu, która jednakże rozwijała się odmiennie na gruncie poszczególnych dyscyplin naukowych, jak również w odniesieniu do wyróżnianych kategorii regionu, a także ewoluowała znacznie w ciągu ostatnich dekad w wyniku dyskusji wewnątrzkrajowych i inspiracji zewnętrznych. W socjologii region jest na ogół pojmowany jako pewien korelat zbiorowości terytorialnej czy też społeczności regionalnej, charakteryzującej się poczuciem wspólnotowości, odrębności w stosunku do sąsiadów i więzi emocjonalnych względem zamieszkiwanego 
obszaru (lub jego własności). Z kolei w etnologii pojęcie regionu często bywa równoznaczne z pojęciem terytorium etnograficznego, tzn. z obszarem zamieszkiwanym przez grupę o podobnych cechach kulturowych (np. języku, wyznaniu, kulturze ludowej), które nadają jej względną odrębność. Region taki charakteryzuje podobieństwo określonego zespołu cech lub zjawisk kulturowych wewnątrz zamieszkiwanego obszaru, a zarazem ich kontrast względem obszarów przyległych (zob. Zawistowicz-Adamska, 1976; Kucharska, 1993). Podobnie u podstaw koncepcji regionu w początkowej fazie rozwoju współczesnej geografii stało założenie, że powierzchnię kuli ziemskiej, jak również jej fragmentów można podzielić na obszary o odrębnym charakterze, wewnątrz których jest dopuszczalne pewne zróżnicowanie w ramach przyjętych kryteriów, ale które traktuje się z perspektywy całościowej jako obszary jednolite. Dlatego też przedstawiciele niektórych dyscyplin chętnie, choć raczej werbalnie posiłkowali się też dorobkiem geografii w zakresie regionu. Należy zaznaczyć, iż na gruncie geografii kierunek regionalny rozwijał się już w ostatnich dekadach XIX wieku (we Francji czy w Niemczech). Wraz z rozwojem i ewolucją geografii regionalnej wśród geografów pojawił się spór o ujęcie regionu. Według jednego stanowiska regiony istnieją obiektywnie (są konkretnymi obiektami), a według innych są narzędziem analizy regionalnej. Ten spór miał przełożenie również na dyskusję o znaczeniu różnych ujęć regionu zarówno dla poznania procesu kształtowania się podstaw regionalistycznych, jak i samego badania tego zjawiska. W połowie XX wieku zaczęto wyróżniać drugi rodzaj regionu — region węzłowy, jednolity, ale ze względu na strukturę powiązań miejscowości położonych na danym obszarze z tzw. ogniskiem (rdzeniem). Podobny charakter ma kategoria regionu administracyjnego czy też politycznego, w którym ośrodek władzy (ognisko) kontroluje i nadzoruje krążenie decyzji w jego częściach składowych. A zatem pod pojęciem regionu administracyjnego ,rozumie się zinstytucjonalizowane terytorialne systemy społeczno-polityczne, w których zbiorowość ludzi trwale zajmuje, zagospodarowuje i [...] kontroluje określone terytorium" (Miszczuk, 2003, s. 29). Z kolei region polityczny wyznaczany jest przez jeden czynnik (własność): ,podległość określonej władzy politycznej, [która] decyduje o jego wyznaczeniu oraz zasięgu" (Koter, 1993, s. 51). Podobne własności nadaje się regionowi historycznemu, za który uznaje się terytorium funkcjonujące jako odrębne w danej epoce historycznej (Topolski, 1969; Podraza, 2006), a zatem często jest traktowany jako twór trwały, a nawet niezmienny (zob. Rykiel, 2001). Stąd też pojawiały się nieraz, zwłaszcza w nauczaniu szkolnym, koncepcje wyróżniania w Polsce tzw. regionów geograficzno-historycznych (Kiełczewska-Zaleska, 1980), które mają być niejako syntezą krain geograficznych i regionów historycznych.

Według Anssi Paasi'ego region jest jednostką terytorialną ukształtowaną instytucjonalnie w toku rozwoju społecznego (Paasi, 1986). Zatem w takim ujęciu region jest produktem społecznym pewnej zbiorowości, a podstawowymi składnikami konstytuującymi go są zbiorowości ludzkie i terytorium. Z perspektywy tych dwóch składników wskazuje się na własności wyróżniające region w przestrzeni ziemskiej. Na ogół są to: (a) podobieństwo wewnętrzne, wyrażające się m.in. 
w cechach kultury, cechach społeczno-politycznych i gospodarczych, poczuciu wspólnotowości lub podległości centrum władzy; (b) wyodrębnienie względem obszarów sąsiednich, wyrażające się m.in. w granicach zarówno realnych, jak i symbolicznych, nazwie zwyczajowej zbiorowości lub terytorium, jak również w tzw. domknięciu regionu.

Skoro pojęcie regionalizmu bywa nierozłącznie związane $\mathrm{z}$ pojęciem regionu, to poszczególne dyscypliny naukowe próbują definiować również to pojęcie na swoje potrzeby badawcze - podobnie jak wcześniej regiony. I tak, na gruncie geografii społeczno-ekonomicznej regionalizm traktowany jest zarówno jako syndrom społeczno-kulturalnych, politycznych i ekonomicznych cech danego obszaru, jak i odnoszony do stanu świadomości społecznej zbiorowości zamieszkującej ten obszar (Rykiel, 1993) oraz do innych przejawów aktywności gospodarczej, kulturowej i politycznej tej zbiorowości (Chojnicki, Czyż, 1992). Z kolei według przedstawicieli nauk o kulturze i etnologii regionalizm stanowi ideę, która wyrasta z potrzeby zachowania, kultywowania i rozwijania swoistych cech kultury (wartości, stylu życia $i$ in.) na obszarze o zauważalnych cechach odrębności regionalnych lub etnicznych, ale też ideą „zmierzającą do utrwalenia i pogłębienia tożsamości społeczno-kulturowej i etnicznej" (Damrosz, 1987, s. 22). Na dążenie społeczności do integracji kulturowej zamieszkanego przez nią obszaru zwrócił uwagę Krzysztof Kwaśniewski (Kwaśniewski, 1993), a dyskurs o przejawach i formach regionalizmu Polski trafnie podsumował Marek Latoszek, wydając pracę zbiorową pt. Regionalizm jako folkloryzm, ruch społeczny i formuta ideologiczno-polityczna (Latoszek, red., 1993). Należy też zwrócić uwagę, że pierwotni autorzy terminu regionalizm - literaci prowansalscy (m.in. ruch Félibrige i Frédéric Mistral; zob. Fournier, 2006) — określili go jako dążenie mieszkańców ich obszaru życia do zachowania odrębności kulturalnej i sprzeciw przeciwko centralizmowi kulturalnemu zwłaszcza miasta stołecznego Paryża. Podobnie działacz galicyjski w XIX wieku Alfredo Brañas określił mianem regionalizmu dążenie do odnowienia swojego historycznego regionu w ramach monarchii hiszpańskiej w oparciu o przeszłość historyczną i silną religijność jego mieszkańców (Brañas, 1889).

Źródłem regionalizmu i zmian społecznych postaw wobec regionu mogą być różnorodne struktury terytorialne, np. działalność zbiorowości ludzkiej. Rykiel, przeprowadzając typologię obserwowanych w Polsce regionalizmów - w układzie 49 ówczesnych województw — próbował ustalić ich źródło (Rykiel, 1993). W związku z tym wyróżnił następujące rodzaje regionalizmu: polityczny, kulturowy, gospodarczy i folklorystyczny, ale też quasi-regionalizmy — w przypadku niejasnej świadomości regionalnej, niewykształconej społeczności regionalnej i działań o ograniczonym zasięgu odwołujących się do interesów regionalnych. Wśród czynników kształtujących i rozwijających świadomość regionalnych mieszkańców w Europie wymienia się: 1) aktywizację ruchów (mniejszości) etnicznych; 2) zmiany struktury administracyjnej i decentralizację systemu władzy; 3) tradycje wieloośrodkowości władzy politycznej oraz doświadczenia historyczne (i mitycz-

62 ne); 4) zderzenie kultur narodowych w strefie pogranicza oraz poczucie odrębności 
kulturowej w regionach; 5) aktywizację grup społecznych (elit) w postaci instytucji współpracy regionalnej (zob. Dobrowolski, 2000; Sowa, red., 2000).

\section{Kontekstualizacja społeczno-geograficzna regionalizmu}

Ważną koncepcją organizującą całe pole badawcze geografii w XX wieku było podejście chorologiczne. Polegało ono na badaniu rozmieszczenia obiektów (zjawisk) oraz relacji przestrzennych $\mathrm{w}$ ujęciu holistycznym, funkcjonalnym i systemowym (zob. Chojnicki, 1973). Również usamodzielniająca się dyscyplina, jaką jest geografia społeczno-ekonomiczna (zwana też geografią człowieka), nadal chętnie korzysta z wzorców badawczych ukształtowanych w okresie pełnej jedności dyscyplinarnej.

Jednakże kontekst przestrzenny stanowiący na gruncie geografii paradygmat bywa krytykowany na gruncie innych nauk społecznych, a czasem sprowadzany do sposobu wizualizacji kartograficznej wyników. Przykładem krytyki mało owocnej roli geografii jest opinia Tomasza Zaryckiego: „Geograficzne próby badania przestrzeni potwierdzają, że niełatwo osiągnąć prawdziwie twórcze, pożyteczne rezultaty badań interdyscyplinarnych, mających za wspólny mianownik pojęcie przestrzeni" (Zarycki, 1998, s. 172). Dalej Zarycki stawia geografom zarzuty, iż na podstawie współwystępowania czy zbieżności dwóch układów przestrzennych zjawisk próbują wyjaśnić istotę występujących prawidłowości, a najczęściej informują ,jedynie o pewnym jego aspekcie" (Zarycki, 1998, s. 173). I stwierdza on m.in., że „określenie zależności przyczynowych to zagadnienie złożone w każdej nauce, a zadanie, przed którym stoją geografowie, nie pozostaje w żaden sposób ułatwione" (Zarycki, 1998, s. 173). Należy zwrócić uwagę, że geografia zarówno w swej części przyrodniczej (geografia fizyczna), jak i w części społeczno-ekonomicznej (geografia człowieka) zdawała sobie sprawę z badania układów złożonych środowiska. Przy czym wykazywała rozwagę, unikając ustalania prostych zależności w kategoriach przyczynowo-skutkowych na rzecz określania mechanizmów oddziaływania czynników, przez co wyprzedzała w tym zakresie ujęcia systemowe tak popularne w różnych naukach od lat 70. XX wieku.

Region - według Prestona E. Jamesa — jest obszarem o dowolnej wielkości, jednorodnym z punktu widzenia pewnych kryteriów, który od obszarów otaczających różni zespół przestrzennie powiązanych cech (James, 1959). Można zatem zauważyć, że region stanowi wyjątkowo rozciągły przestrzennie obiekt w geografii (zob. Czerny et al., 1999). Zależność skali wielkościowej regionu — w zależności od poziomu analizy regionalnej - przedstawił Marek Dutkowski (Dutkowski, 2008). W takim ujęciu regiony przyjmują postać megaregionów - w formie kontynentów lub grupy państw, jak również mikroregionów w postaci jednostki 
sąsiedzkiej czy zespołu zabudowań. Jednak wielu geografów regionalizm wiąże jedynie z największymi regionami w skali Polski. I tak, Rykiel, charakteryzując typy ruchów regionalnych w Polsce, odniósł je do ówczesnego podziału administracyjnego na jednostki najwyższego rzędu, czyli na 49 województw (Rykiel, 1993). Z kolei Zbyszko Chojnicki sugerował, że rozwojowi więzi regionalnych sprzyja m.in. instytucjonalizacja regionu i współcześnie należałoby go wiązać również z jednostkami administracyjnymi najwyższego rzędu (Chojnicki, 1996). Jednakże tenże Rykiel zauważył, że źródłem regionalizmu kulturalnego w ówczesnych województwach białostockim i nowosądeckim były tendencje regionalistyczne głównych mniejszości kulturowych (grup etnicznych). Do grup regionalnych sprzyjających rozwojowi regionalizmu przedstawiciele różnych dyscyplin zaliczali m.in. Kaszubów, Podhalan, Kurpiów czy mniejszość białoruską na Podlasiu.

Według Chojnickiego uzyskanie przez region statusu administracyjnego stanowi kulminacyjny punkt procesu jego instytucjonalizacji, a przez to — źródło utrwalenia postaw regionalistycznych jego mieszkańców (Chojnicki, 1996). Należy jednak zwrócić uwagę, że w warunkach polskich wyraźny związek emocjonalny ludności z miejscem zamieszkania występował pomimo braku wsparcia instytucji typowo administracyjnych dla przejawów form regionalizmu. Takie postawy regionalistyczne w Polsce szczególnie widoczne były w okresie lat 90., w trakcie dyskusji o zmianie podziału administracyjnego kraju, gdy ujawniały się ruchy regionalne bliskie koncepcji wielkich regionów określanych mianem regionów geograficzno-historycznych czy reliktowych.

Inna ważną cechą regionu jest jego granica, wyznaczająca jego zasięg terytorialny, a zarazem uważana za warunek konieczny jego istnienia (zob. Grigg, 1967). Z kolei Jerzy Damrosz zwrócił uwagę, że niektóre granice o wymiarze kulturowym mają charakter nielinearny, czyli stanowią strefę przejściową (Damrosz, 1987). Oczywiście taka granica ulega rozmyciu, ale na gruncie całej geografii (w tym geografii fizycznej) postrzegano stopniowalność natężenia uwzględnianych własności (cech), przy czym starano się określić takie kryteria analityczne, by wyznaczyć jednoznaczny przebieg granic. Należy też zwrócić uwagę, iż na gruncie tradycyjnej geografii występuje spór o trwałość regionu. W geografii społeczno-ekonomicznej region często traktowany jest jako twór przestrzenno-fazowy, który nawet może ulec zanikowi; w geografii fizycznej natomiast - ze względu na mniej zmienne cechy przyrodnicze go konstytuujące - uważa się go za obiekt trwały z perspektywy życia wielu pokoleń ludzkich.

Nurt behawioralny (a w szczególności kierunek percepcyjny) ujawniał się sporadycznie w geografii anglosaskiej, ale szczególnym impulsem do jego rozwoju była praca socjologa i urbanisty Kevina Lyncha (Lynch, 1960). Również podobne badania dotyczące struktury przestrzennej miast podjęto na gruncie geografii polskiej w latach 80. (zob. Manikowska, Matykowski, 1984; Bartnicka, 1986; 1989; Domański, Prawelska-Skrzypek, 1986; Libura, 1988). Następnie rozwinięto też badania geograficzne nad postrzeganiem przestrzennym w postaci konstruktu przestrzennej percepcji przeciętnych ludzi - regionu wernakularnego (Jordan,

64 Rowntree, 1979; Zelinsky, 1980). Jednakże o ile rdzeń tak pojmowanego regionu 
bywa łatwo identyfikowalny, o tyle jego granice są często rozmyte, gdyż różnią się jednostkowo (Rubinstein, 2002). Lynch wyróżnił w wyobrażeniach przestrzennych badanych ludzi węzły, punkty orientacyjne, drogi, krawędzie i bariery oraz obszary (powierzchnie), które można sprowadzić do układów o charakterze liniowym (np. granic regionu, rzek), powierzchniowym (np. jednostek podziału administracyjnego, które w pełni lub częściowo należą do regionu) lub punktowym (np. układu najważniejszych miast zaliczonych do regionu) (Lynch, 1960). W przypadku badań dotyczących wyobrażeń regionu węzły można też identyfikować z symboliczną bądź realną (w wymiarze funkcji administracyjnych czy społeczno-gospodarczych) jego stolicą, inne układy punktowe $-\mathrm{z}$ tzw. tłem osadniczym (czyli wskazywaniem innych znaczących miejscowości regionu), z kolei obszary — z gminami uznawanymi za składowe regionu, a krawędzie - np. z granicami, w tym granicami reliktowymi funkcjonującymi w świadomości jego mieszkańców.

Podejmując analizę dotychczasowych rezultatów badań nad regionalizmem na Śląsku Cieszyńskim z perspektywy społeczno-geograficznej, należy zwrócić uwagę na sytuację problemową ujętą $\mathrm{w}$ formie kilku zagadnień. Ważnymi kwestiami są zasięg przestrzenny współczesnego regionalizmu określanego mianem przedmiotowego, trwałość jego granic, a także stopniowalność jego natężenia. Specyficzną barierę w powstawaniu czy kreowaniu regionu wernakularnego tworzy granica państwowa (w latach 1920 — 1938 i od 1945 roku), która posiadała różny stopień przenikalności, a od grudnia 2007 roku jest już mało odczuwalna. Z punktu widzenia socjologii, ale też geografii społecznej, struktura etno-społeczna całego Śląska Cieszyńskiego, jej zróżnicowanie po obu stronach granicy, jak również przemiany zaznaczone przez migracje ekonomiczne związane są z procesami uprzemysłowienia i urbanizacji. $\mathrm{Z}$ kolei istotnym działaniem na rzecz regionalizmu kreatywnego były działania na poziomie samorządowym dążące zarówno do restytucji powiatu, jak i powiązań transgranicznych pomiędzy polską i czeską częścią Śląska Cieszyńskiego.

\section{Śląsk Cieszyński jako twór przestrzenny}

Świadomość i tożsamość regionalna traktowane jako odrębny segment świadomości społecznej kształtowane są nie tylko pod wpływem procesów krystalizacji przestrzenno-funkcjonalnej określonego obszaru (który nabiera charakteru regionu). Ważnym czynnikiem ich rozwoju bywają także edukacja szkolna, przekaz rodzinny i oddziaływanie mediów regionalnych. Dlatego też wyobrażenia przestrzenne regionu kształtują się w wyniku selektywnego odwoływania się do dziedzictwa historycznego (pamięci tak historycznej, jak i mitycznej), dziedzictwa społeczno-kulturowego (np. odrębności etno-lingwistycznych) czy współczesnych odrębności politycznych, gospodarczych, a nawet przyrodniczych tegoż obszaru, który w świadomości jednostek przybiera postać konkretnego 
obiektu przestrzennego. Ważnym wymiarem samookreślenia mieszkańców takiego obszaru jest formalne lub nieformalne zdefiniowanie jego zasięgu terytorialnego, jak również nadanie mu nazwy. W odniesieniu do polskiej części analizowanego obszaru współcześnie najczęściej funkcjonuje określenie Śląsk Cieszyński, choć w użyciu nadal pozostaje również nazwa Księstwo Cieszyńskie (np. na naklejkach na pojazdy). A zatem najważniejszym konstruktem poznawczym, na podstawie którego mieszkańcy kształtują swoją świadomość i tożsamość regionalną, jest Śląsk Cieszyński i jego pamięć historyczna.

Po śmierci polskiego monarchy Bolesława Krzywoustego Śląsk stał się jedną z dzielnic książęcych wedle testamentu przyznaną najstarszemu synowi, Władysławowi II, obejmującą dorzecze górnej i środkowej Odry. W wyniku dalszych podziałów feudalnych i na podstawie systemu dziedziczenia powstawały na tych ziemiach nowe księstwa. I tak, Księstwo Cieszyńskie powstało prawdopodobnie w latach 80 . XIII wieku poprzez podział między synów przez księcia Władysława Opolskiego. Jego pierwszym władcą został w 1290 roku Mieszko I, książę cieszyńsko-oświęcimski. W następnych wiekach w wyniku dalszego podziału Księstwa powstało Księstwo Oświęcimskie (w 1317 roku, po śmierci księcia Mieszka I) i Księstwo Zatorskie (wydzielone z Księstwa Oświęcimskiego w 1445 roku). Oba te księstwa zostały w 1564 roku inkorporowane do Korony Polskiej, gdy Księstwo Cieszyńskie pozostawało lennem Królestwa Czech, a od 1526 roku, podobnie jak państwo czeskie - we władaniu Habsburgów austriackich. W wyniku wojen prusko-austriackich w latach 1740 — 1763 (I, II i III wojna śląska) we władaniu Habsburgów pozostała tylko niewielka część Śląska, tj. dwa nieduże subregiony: Śląsk Cieszyński i Śląsk Opawski (Snoch, 1991; Panic, 2001; Spyra, 2001). W 1849 roku uchwalono reformę struktury terytorialnej Cesarstwa Austrii, którą zaczęto realizować od 1 stycznia 1850 roku. Do takich krajów Cesarstwa należały m.in.: Królestwo Galicji i Lodomerii (obejmujące ziemie Rzeczypospolitej przyłączone do Austrii w 1772 roku), Królestwo Czech, Margrabstwo Moraw oraz Śląsk Austriacki ze stolicą w Opawie.

Pod koniec I wojny światowej Ziemia Cieszyńska stała się przedmiotem sporu pomiędzy polskimi i czeskimi działaczami niepodległościowymi. W dniach 12-19 października w Cieszynie ukonstytuowała się Rada Narodowa dla Księstwa Cieszyńskiego utworzona przez polskich działaczy niepodległościowych. Z kolei działacze czescy nieco później (29 października 1918 roku) powołali w Ostrawie Śląskiej Zemský národni výbor pro Slezsko na rzecz przyłączenia tych ziem do Czechosłowacji, korzystając z wsparcia władz nowego państwa, w dzień po proklamowaniu niepodległości (28 października). Takiego wsparcia nie otrzymali działacze polscy, gdyż wtenczas nie funkcjonowało centrum władzy niepodległościowej Polski. W dniu 5 listopada 1918 roku działacze polscy i czechosłowaccy na Śląsku Cieszyńskim podpisali porozumienie w sprawie tymczasowego przebiegu granicy na tym obszarze, pozostawiając ostateczną ugodę w kompetencji powstających władz państwowych obu stron. Stronie czechosłowackiej przypadł powiat frydecki oraz część obszarów wiejskich powiatu frysztackiego, a stronie polskiej — powiaty bielski, cieszyński i część frysztackiego (zob. rys. 1). 
Władze polskie zarządziły wybory do Sejmu Ustawodawczego w dniu 26 stycznia 1919 roku i objęły tym zarządzeniem ziemie pod polską kontrolą na Śląsku Cieszyńskim, tworząc tam okręg wyborczy. Władze czechosłowackie uznały, iż tymczasowy charakter granicy poprzez wybory do Sejmu może zostać utrwalony, i w związku z tym podjęły działania wojenne, naruszając tę tymczasową granicę na trzy dni przed wyborami - w dniu 23 stycznia 1919 roku. Wojska czechosłowackie (w liczbie ok. 16 tys. żołnierzy), które przekroczyły tymczasową granicę, w swych założeniach strategicznych miały na celu zajęcie całego Śląska Cieszyńskiego — łącznie z miastem Bielsko. Ten plan działań militarnych mógł się powieść, gdyż władze Polski skupiały się przede wszystkim na ustalaniu granicy państwa na wschodzie, a drugorzędnie traktowały kwestię Śląska Cieszyńskiego traktowały drugorzędnie (Nowak, 2001; 2008). Należy też zaznaczyć, że przedstawiciele polskiej myśli niepodległościowej, jak również autorzy podręczników i monografii polskich pod koniec okresu zaborów w granicach odrodzonego państwa polskiego widzieli m.in. Śląsk Cieszyński (zob. Chociszewski, 1892; Romer, 1916; Romer, Weinfeld, 1917; Sosnowski, 1918; Loth, 1919; Eberhardt, 2006). Tak więc Śląsk Cieszyński zaznaczał się w przypadku odrodzenia tych państw jako możliwy obszar sporów (zob. Wituch, 2001).

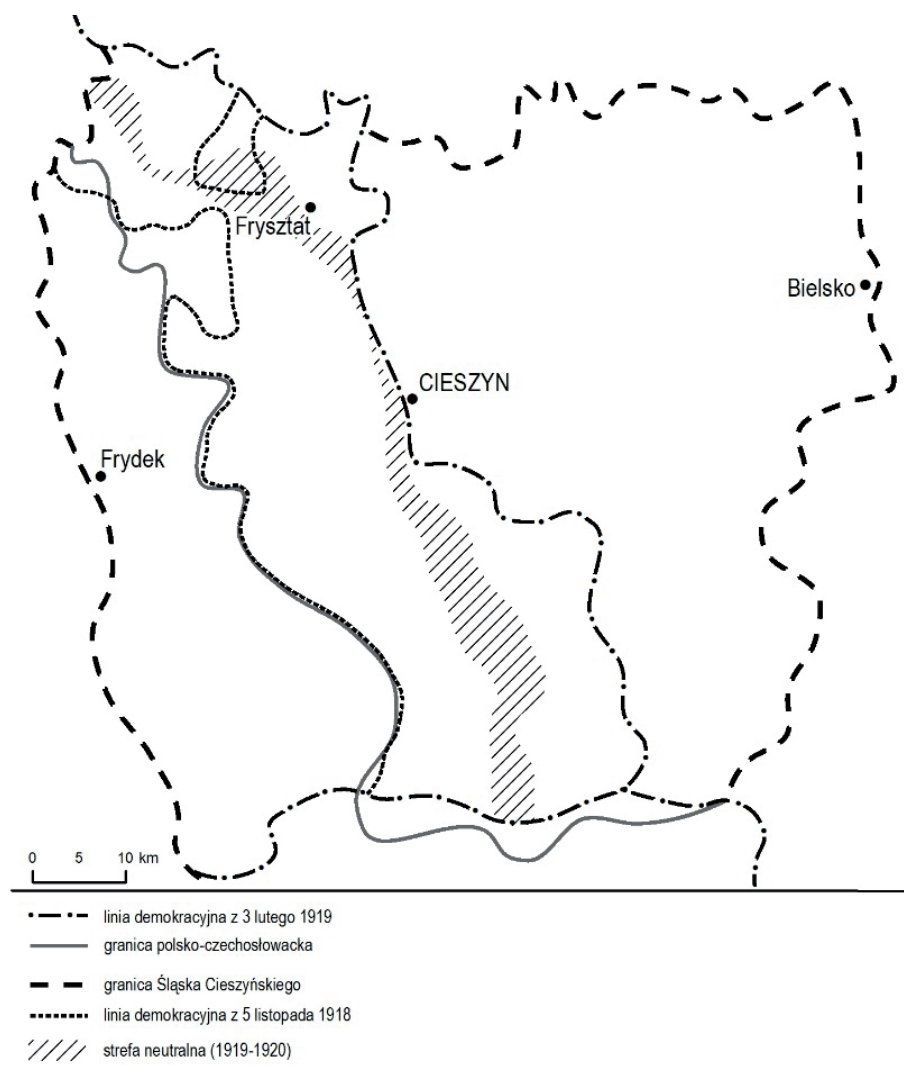

Rys. 1. Granice Śląska Cieszyńskiego w ramach monarchii austriackiej i płynność granic na tym obszarze w latach 1918-1938 
Rozpoczynając ofensywę, przeważające czechosłowackie siły militarne, przesuwając się na wschód dotarły aż do linii Skoczów—Wisła, a w dniach 28-30 stycznia 1919 roku stoczyły pod Skoczowem nierozstrzygniętą bitwę z nielicznymi oddziałami polskimi dowodzonymi przez pułkownika Franciszka Latinika. W dniu 3 lutego 1919 roku państwa Ententy nakazały obu stronom rozejm, a następnie wydały decyzję o przeprowadzeniu w byłym Księstwie Cieszyńskim plebiscytu. W dniu 2 lutego 1920 roku Komisja Administracyjna Ententy wprowadziła tymczasowy podział administracyjny Śląska Cieszyńskiego na dwie prefektury: zachodnią i wschodnią. Ze względu na wojnę polsko-bolszewicką i trudną sytuację na tym froncie (natarcie Armii Czerwonej) Polska zrezygnowała z plebiscytu na Śląsku Cieszyńskim w lipcu 1920 roku i zaakceptowała jego ostateczny podział dokonany przez Radę Ambasadorów w dniu 28 lipca 1920 roku (zob. rys. 1). Podział ten w zasadzie nawiązywał do tymczasowej linii rozejmowej z lutego 1919 roku, a granica przebiegała wzdłuż rzeki Olzy. Władze Polski, pamiętając przewagę militarną i dyplomatyczną Czechosłowacji w kwestii Śląska Cieszyńskiego w okresie po I wojnie światowej, wykorzystały jej trudną sytuację polityczną jesienią 1938 roku (roszczenia niemieckie do obszaru Sudetów) - wysłano ultimatum do rządu tego kraju w dniu 1 października, a następnie zajęto Zaolzie (czyli większość czechosłowackiej części Śląska Cieszyńskiego). Po zakończeniu II wojny światowej przywrócono przebieg granicy z okresu międzywojennego, z lat 1920 - 1938. Po II wojnie światowej w nowej sytuacji politycznej w tej części Europy Polska i Czechosłowacja podpisały układ o przyjaźni i wzajemnej pomocy w dniu 10 marca 1947 roku wraz z specjalnym załącznikiem, w którym obie strony zobowiązywały się rozstrzygnąć sporne kwestie terytorialne w ciągu dwóch lat. Jednakże umowę o ostatecznym wytyczeniu granicy pomiędzy obu państwami zawarto dopiero w dniu 13 czerwca 1958 roku, a drobna wymiana terytoriów nie została jeszcze zakończona. Nowy traktat o stosunkach dobrosąsiedzkich i współpracy przyjaznej Polska i Czechosłowacja podpisały w październiku 1991 roku, a po rozpadzie tego państwa w 1993 roku Polska zawarła dwa porozumienia o współpracy transgranicznej — ze Słowacją (18 sierpnia 1994 roku) i z Republiką Czeską (8 września 1994 roku) (zob. Siwek, Kulczyńska, Matykowski, 2009).

W odniesieniu do Śląska Cieszyńskiego funkcjonuje również terminologia zabarwiona politycznie. Takimi określeniami fragmentu tego obszaru są m.in. Zaolzie czy czeski termin Těšinsko. Pierwsze polskie określenie ma oznaczać w ogólności część Śląska Cieszyńskiego, należącą do Republiki Czeskiej. Jednakże w tym przypadku występuje kilka wariantów zasięgów: (a) część dawnego Księstwa Cieszyńskiego, która znalazła się we władaniu Czechosłowacji — czyli obszar pomiędzy rzekami Olzą a Ostrowicą; (b) część pomiędzy tymczasową granicą z dnia 5 listopada 1918 roku a granicą państwową z 1920 roku (obszar o przewadze etnosu polskiego); (c) obszar zajęty przez Polskę w dniu 2 października 1938 roku. Podobnie Těšínsko może oznaczać: (a) cały historyczny Śląsk Cieszyński; (b) czeską część Śląska Cieszyńskiego; (c) najbliższą okolicę Czeskiego Cieszyna, w tym odpowiednik czeskiego powiatu z siedzibą w tym mieście 68 (zob. Gąsior, 2008). 
Ważną strukturą terytorialno-organizacyjną Śląska Cieszyńskiego był podział administracyjny wprowadzony przez Cesarstwo Austrii w 1850 roku. Księstwo tuż przed wybuchem I wojny światowej (w 1910 roku) tworzyły trzy powiaty: bielski, cieszyński i frysztacki oraz dwa miasta z odrębnym statusem: Bielsko i Frydek. Po podziale Śląska Cieszyńskiego w 1920 roku oraz ustabilizowaniu się sytuacji na sąsiednim Górnym Śląsku w polskiej części funkcjonowały dwa powiaty: bielski i cieszyński (w znacznie okrojonym zasięgu — na granicy na Olzie). Oba powiaty włączono do autonomicznego województwa śląskiego. Ten układ podziału terytorialno-administracyjnego przetrwał do 1951 roku, gdy doszło do połączenia dwóch miast: Bielska (położonego peryferyjnie w byłym Księstwie) i Białej (w byłej Galicji). Pod wpływem tych zmian administracyjnych (dodatkowo przesunięcie gminy Strumień z powiatu bielskiego do cieszyńskiego) oraz silnych procesów uprzemysłowienia i wzrostu demograficznego miasta Bielska nastąpiło dalsze rozmycie tradycyjnej granicy byłego Księstwa na wschodzie. Po likwidacji powiatów i utworzeniu nowych województw w 1975 roku Bielsko-Biała stało się symbolicznym centrum nowo kreowanego regionu Podbeskidzia, a Śląsk niejako zaczął się kurczyć do gmin związanych z ośrodkiem w Cieszynie. W 1991 roku część gmin położonych wokół Cieszyna utworzyła Związek Komunalny Ziemi Cieszyńskiej, który miał stanowić namiastkę nieistniejącego wtedy powiatu oraz płaszczyznę społeczną umacniania więzi subregionalnej, jak również twór ułatwiający zapowiadaną wówczas restytucję powiatów w Polsce.

Również po stronie czeskiej (czechosłowackiej) wykorzystano struktury administracyjne z czasów panowania habsburskiego. W czeskiej części Śląska Cieszyńskiego także funkcjonował podział na powiaty jako jednostki terytorialno-administracyjne, który został zniesiony w 2003 roku. Struktura powiatowa w Republice Czeskiej została zachowana jako podział o charakterze terytorialno-statystycznym. Przez lata funkcjonował również powiat Český Těšín utożsamiany z subregionem Těšínsko, chociaż od 2007 roku obszar ten jest częścią jednostki terytorialno-statystycznej Karwina, a południowa czeska część tego regionu historycznego — jednostki Frýdek-Místek.

\section{Wyobrażenia o Śląsku Cieszyńskim}

Polski geograf społeczno-ekonomiczny Chojnicki — inspirując się ujęciem regionu Paasi'ego (Paasi, 1986) - sformułował model kształtowania się regionu, składający się z czterech faz (Chojnicki, 1996). Z punktu widzenia współczesnego procesu regionalizmu na Śląsku Cieszyńskim należy zwrócić uwagę na dwie z tych faz: (a) kształtowania i rozwoju świadomości regionalnej i (b) rozwoju instytucjonalnego regionu.

Najstarszą działającą organizacją o charakterze regionalnym na Śląsku Cieszyńskim jest powstała w 1885 roku Macierz Szkolna dla Księstwa Cieszyńskiego, 
wspierająca rozwój oświaty i edukacji szkolnej w środowisku polskim tego kraju Cesarstwa Austrii. Po włączeniu wschodniej części dawnego Księstwa do Polski zmieniono nazwę tej organizacji na Macierz Ziemi Cieszyńskiej. Macierz działa nadal, a podstawową formą organizacji są koła, zlokalizowane na ogół w miejscowościach powiatu cieszyńskiego, choć pojedyncze działały także poza regionem, m.in. w Katowicach.

Po przyłączeniu części Śląska Cieszyńskiego w 1920 roku do Polski administracja powiatowa funkcjonowała w dwóch ośrodkach: Cieszynie i Bielsku. Powiaty te przyłączono w 1922 roku do województwa śląskiego. Jednakże po II wojnie światowej, w 1951 roku połączono dwa miasta położone nad rzeką Biała - Bielsko i Białą - a nowy powiat wykraczał znacznie na wschód poza granicę historyczną Śląska Cieszyńskiego. Od tego momentu zaczęła słabnąć identyfikacja z tym regionem w Bielsku-Białej i sąsiednich gminach. W 1975 roku zlikwidowano ten szczebel administracji terytorialnej, choć w nadal Cieszyn zachował wpływ na otaczające gminy w zakresie sądownictwa, prokuratury i lecznictwa, a także był ważnym ośrodkiem edukacji na poziomie ponadpodstawowym. Po przemianach polityczno-ustrojowych i społeczno-gospodarczych Polski na przełomie lat 80 . i 90. rozpoczęła się dyskusja o reformie terytorialno-administracyjnej kraju i przywróceniu powiatów oraz utworzeniu większych terytorialnie województw. Dlatego działacze lokalni powołali w 1991 roku z części gmin wokół Cieszyna Związek Komunalny Ziemi Cieszyńskiej, składający się z 12 gmin i będący namiastką powiatu (poza tym 2 gminy, Jasienica i Zebrzydowice, miały status obserwatora). W 1999 roku odtworzono powiat cieszyński, w którego skład weszło 12 gmin (z wyjątkiem Jaworza i Jasienicy włączonych do powiatu bielskiego). Z kolei Związek Komunalny uległ rozwiązaniu 10 lat po reformie administracyjnej i na jego miejsce utworzono Stowarzyszenie Samorządowe Ziemi Cieszyńskiej będące kontynuacją poprzedniej organizacji.

Pewnym przejawem przywrócenia powiązań pomiędzy obu częściami podzielonego granicą Śląska Cieszyńskiego była umowa o współpracy regionalnej zawarta w dniu 24 marca 1993 roku pomiędzy Związkiem Komunalnym Ziemi Cieszyńskiej a dwoma podmiotami czeskimi: Związkiem Komunalnym Regionu Karwina (Sváz obcí Regionu Karvina) i Radą regionalną Rozwoju i Współpracy z siedzibą w Trzyńcu (Regionální rada rozvoje a spolupráce se sídlem v Třinci). Jej celem było m.in.: (a) sprzyjanie rozwojowi kultury Śląska Cieszyńskiego; (b) wspieranie rozwoju ruchu turystycznego; (c) rozwiązywanie problemów w celu usprawnienia ruchu granicznego; (d) koordynacja działań regionalnych w zakresie wspólnych zainteresowań. Później, bo w dniu 22 kwietnia 1998 roku, współpraca ta przyjęła formę euroregionu, gdyż reprezentujący stronę czeską Regionální sdružení česko-polské spolupráce Těšínského Slezska i reprezentujące stronę polską Stowarzyszenie Rozwoju i Współpracy Regionalnej „Olza” (powstałe z inicjatywy Związku Komunalnego) podpisały umowę o utworzeniu regionu transgranicznego Śląsk Cieszyński. Na siedziby euroregionu wybrano miasta Cieszyn oraz Český Těšín. Należy zaznaczyć, że zasięg przestrzenny euroregionu Śląska Cieszyńskiego

70 po stronie polskiej nie pokrywa się z historycznymi granicami Księstwa Cieszyń- 
skiego, albowiem w skład euroregionu weszły miasto Jastrzębie-Zdrój oraz gmina Godów, które powszechnie zaliczane są do Górnego Śląska; do euroregionu nie przystąpiła też większość gmin powiatu bielskiego (z wyjątkiem Jaworza i Jasienicy). Wymienione instytucje - obok domu, szkoły, związków wyznaniowych i mediów — zapewne kształtowały współczesne postawy regionalistyczne niewielkiego regionu, jakim jest Śląsk Cieszyński.

Jednym z istotnych wymiarów świadomości regionalnej jest identyfikacja mieszkańców danego regionu z określonym terytorium. Najczęściej zasięg przestrzenny regionu można ustalić na podstawie badań ankietowych dotyczących: (a) układu punktowego, czyli miast (miejscowości) zaliczanych do regionu; (b) układów powierzchniowych, czyli gmin uznanych przez respondentów za należące do Śląska Cieszyńskiego lub jednostek fizyczno-geograficznych tworzących region; (c) symbolicznych granic regionu. W połowie lat 90. takie badania nad zasięgiem Śląska Cieszyńskiego, stosując różne sposoby określania własności i ich pomiaru, przeprowadzili m.in. Grażyna Prawelska-Skrzypek i Bolesław Domański (1997), Halina Rusek i Lesław Werpachowski (1997) oraz Roman Matykowski (1997; 2017).

Prawelska-Skrzypek i Domański objęli badaniem ankietowym 400 dorosłych mieszkańców polskiej części Śląska Cieszyńskiego, którzy spośród 14 miejscowości po stronie polskiej i 8 po stronie czeskiej wybierali te z nich, które stanowiły podstawę identyfikacji regionalnej z określonym terytorium, z ,ich ziemią" (Prawelska-Skrzypek, Domański, 1997). W tym zestawie miejscowości figurowało jedynie miasto Cieszyn, a część respondentów traktowała je formalnie jako miasto polskie, a część jako jeden transgraniczny zespół miejski; stąd to w wykazie tym nie ma miejscowości Cieszyn Czeski. Najwięcej wskazań uzyskały następujące miasta: Skoczów (96\%), Cieszyn (94\%), Ustroń (85\%) i Wisła (85\%) oraz ze znacznie mniejszą intensywnością (powyżej 50\%) Strumień oraz wsie gminne Chybie i Istebna. Część respondentów (w przedziale 31-50\% wskazań) za miasto ziemi cieszyńskiej uznawała Bielsko-Białą. Autorzy badań wskazywali też, że „w niektórych częściach bardzo wyraźna jest granica historyczna, np. między Zwardoniem a Istebną czy Strumieniem a Pszczyną" (Prawelska-Skrzypek, Domański, 1997, s. 49), gdzie zaznaczył się wyraźny skok w poziomie wskazań.

Z kolei Rusek i Werpachowski badaniami ankietowymi objęli młodzież po obu stronach granicy w Cieszynie (175 osób) i na Zaolziu (93 młodych Polaków) (Rusek, Werpachowski, 1997). W tym przypadku respondenci mieli potwierdzić przynależność do Śląska Cieszyńskiego 11 miejscowości polskich oraz 5 miast po stronie czeskiej. Respondenci mogli potwierdzić przynależność miejscowości do regionu, odrzucić ją lub nie wyrazić opinii w tym zakresie. Najwięcej wskazań pozytywnych wśród respondentów po stronie polskiej otrzymały następujące miejscowości: Ustroń (98,3\%), Wisła (87,4\%), Istebna (70,3\%), Strumień $(64,6 \%)$ i położony po stronie czeskiej Jabłonków (41,1\% na tak, 31,4\% na nie). Kolejnymi miejscowościami, które otrzymały jednak więcej wskazań negatywnych niż pozytywnych były: Bielsko (40,6\%), Zebrzydowice (36,6\%), Trzyniec (33,7\%) i Chybie (32,6\%). Wśród respondentów mieszkających w czeskiej części Śląska 
Cieszyńskiego najwięcej wskazań pozytywnych otrzymały: Trzyniec (96,8\%), Jabłonków (95,6\%), Karwina (89,2\%), Wisła (84,9\%), Ustroń $(76,3 \%)$, Istebna $(68,8 \%)$, Strumień $(64,6 \%)$, Bielsko (61,3\%), Frydek-Mistek (51,6\%), Ostrawa (44,1\%), Strumień (39,8\%) i Żywiec (39,7\%).

W przeprowadzonych we wrześniu 1995 roku przez Matykowskiego badaniach ankietowych wśród mieszkańców Śląska Cieszyńskiego (m.in. Cieszyna, Skoczowa, Ustronia i Wisły; łącznie 123 osoby) zapytano m.in. o najważniejsze miejscowości Śląska Cieszyńskiego, przy czym pytanie miało charakter otwarty i respondenci czasem ograniczali się do wskazania jedynie dwóch miejscowości (Matykowski, 1997). Podstawowe tło Śląska Cieszyńskiego w opinii ankietowanych stanowiły miasta: Cieszyn (99,2\% respondentów), Ustroń (79,7\%), Skoczów i Wisła (65,9\%). Trzy inne wymienione przez respondentów miejscowości tworzyły tło drugorzędne (Brenna, Strumień i Bielsko-Biała — centrum Podbeskidzia i stolica ówczesnego województwa), a do tła trzeciorzędnego zaliczono 12 miejscowości, w tym 5 miast położonych na terenie Republiki Czeskiej (Czeski Cieszyn, Karwina, Trzyniec, Frydek-Mistek i Ostrawa Śląska/Polska).

W sierpniu 2000 roku - wkrótce po reformie administracyjnej (likwidacji województwa bielskiego oraz restytucji powiatu cieszyńskiego) — wśród 76 młodych mieszkańców Cieszyna (w wieku 14-29 lat) przeprowadzono badania dotyczące najważniejszych miejscowości regionu i jego zasięgu przestrzennego. Najwięcej wskazań ankietowanych — przy zastosowaniu pytania otwartego w tym zakresie - uzyskały miejscowości: Cieszyn (94,7\%), Ustroń (88,2\%), Skoczów (86,8\%), Wisła (82,9\%), Strumień (34,2\%) i Zebrzydowice (26,3\%); Bielsko² jako część Śląska Cieszyńskiego wskazało jedynie 13,2\% respondentów. Należy też zaznaczyć, że aż 64,5\% ankietowanych uznało, iż współczesny Śląsk Cieszyński można identyfikować z powiatem cieszyńskim.

W czerwcu 2009 roku podjęto kolejne badania ankietowe w Cieszynie dotyczące postrzegania Śląska Cieszyńskiego przez mieszkańców (150 osób, w tym 86 kobiet) (Matykowski, 2017). W związku z otwarciem granicy i wzrostem ruchliwości przestrzennej mieszkańców po obu stronach Olzy zapytano respondentów o przynależność 9 miejscowości położonych po czeskiej stronie Śląska Cieszyńskiego i 17 miejscowości położonych po polskiej stronie, nawiązując do techniki badań przedstawionych przez Prawelską-Skrzypek i Domańskiego. Jedenaście miejscowości powiatu cieszyńskiego ponad $80 \%$ respondentów uznało za wchodzące w skład Śląska Cieszyńskiego; należały do nich: Cieszyn (98\%), Skoczów (95\%), Ustroń (93\%), Wisła (92\%), Strumień (90\%), Goleszów (90\%), Zebrzydowice (88\%), Istebna (87\%), Chybie (82\%), Brenna (82\%) i Hażlach (81\%). Po stronie czeskiej z 8 miast najwięcej wskazań uzyskały: Czeski Cieszyn (81\%), Jabłonków (79\%), Trzyniec (78\%) i Karwina (77\%); najmniej wskazań otrzymały peryferyjnie położone Frydek-Mistek (49\%) i Ostrawa (14\%). Podobnie — położone na pograniczu lub poza granicami polskiej części historycznego Księstwa

${ }^{2} \mathrm{~W}$ pytaniu otwartym respondenci z Cieszyna posługiwali się nazwą Bielsko, a nie oficjalną 
Cieszyńskiego miejscowości Zwardoń (39\%), Bielsko-Biała (22\%), Żywiec (18\%) i Pszczyna (17\%) zdecydowana większość respondentów uznała za nienależące do Śląska Cieszyńskiego.

Na przełomie czerwca i lipca 2008 roku przeprowadzono ${ }^{3}$ badania ankietowe na niewielkiej próbie (52 osoby) wśród mieszkańców Wisły, dotyczące niektórych wyobrażeń o regionie. Wszyscy respondenci uznali, że najważniejszym miastem Śląska Cieszyńskiego i niejako jego stolicą jest Cieszyn. Z kolei najważniejszymi miejscowościami regionu, obok jego symbolicznej stolicy, były Ustroń (100\%), Wisła (92,3\%), Skoczów (62,3\%) i Istebna (30,8\%). Aż 94,2\% respondentów uznało, że ich region Śląsk Cieszyński się kurczy i raczej ogranicza swym zasięgiem do powiatu cieszyńskiego, a dla połowy ankietowanych Olza stanowi symboliczną granicę ich regionu.

Interesującą kwestią związaną z postawami regionalistycznymi mieszkańców na Śląsku Cieszyńskim są najważniejsze postaci związane z tym regionem. Należy zwrócić uwagę, że w odpowiedzi na pytanie otwarte w tym obszarze respondenci wymieniali szereg nazwisk, np. znacznie więcej niż miejscowości istotnych w regionie, choć w wyniku tych wskazań struktura ważniejszych postaci była zazwyczaj rozdrobniona. Może to świadczyć o roli edukacji historycznej w tym zakresie. Respondenci w badaniach ankietowych z 1995 roku za najważniejsze postaci związane z ziemią cieszyńską uznali: nauczyciela ze Skoczowa i pisarza Gustawa Morcinka (59,9\%); XX-wieczną pisarkę Zofię Kossak-Szczucką (25,2\%); mieszkającą przez część swego życia w Górkach Wielkich; kapłana katolickiego z przełomu XVI i XVII wieku, a jednocześnie świętego (od 1995 roku), Jana Sankandra (19,5\%); XIX-wiecznego działacza społecznego Pawła Stalmacha $(12,2 \%)$; działacza politycznego z przełomu wieków, doktora Jana Michejdę (6,5\%). Z kolei w badaniach z 2008 roku przeprowadzonych wśród mieszkańców Wisły na czołowych pozycjach wśród głównych postaci Śląska Cieszyńskiego znaleźli się przedstawiciele miejscowi, tj.: Adam Małysz — skoczek narciarski (61,5\%); Bogumił lub Bogdan Hoff — krajoznawca (42,3\%); Julian Ochorowicz psycholog i działacz społeczny (21,2\%); Paweł Stalmach (15,4\%); Stanisław Hadyna - założyciel Zespołu Pieśni i Tańca „Śląsk” (15,4\%); Jerzy Buzek $(13,5 \%)$ - premier RP i europoseł; Jan Olbrycht (13,5\%) — burmistrz Cieszyna, marszałek Sejmiku Województwa Śląskiego, europoseł. W badaniach ankietowych z 2009 roku za najważniejsze postaci związane z ziemią cieszyńską respondenci uznali: XIX-wiecznego działacza społecznego Pawła Stalmacha (25,3\%); pisarza Gustawa Morcinka (23,3\%) - mieszkańca Skoczowa; działaczy politycznych z przełomu wieków Tadeusza Regera (16\%) i doktora Jana Michejdę (10,7\%); księdza Józefa Londzina (10,7\%) - burmistrza Cieszyna w latach 1927-1929; legendarnych Trzech Braci: Leszka, Cieszka i Bolka (13,3\%) — związanych z powstaniem miasta Cieszyna, których pamięć w świadomości mieszkańców utrwalana jest przez coroczne ich święto (w czerwcu); księcia piastowskiego Mieszka I (13,3\%); deputowanego do Parlamentu Europejskiego Jana Olbrychta

\footnotetext{
${ }^{3}$ Przez autora niniejszego artykułu. 
(7,3\%); skoczka narciarskiego z Wisły Adama Małysza (6\%); działacza narodowego i społecznego Jerzego Cienciałę (6\%).

Podobne badania ankietowe wśród 920 mieszkańców nad poczuciem przynależności do Śląska Czeskiego przeprowadzili w listopadzie 1998 roku Jaromír Kaňok i Tadeusz Siwek (Kaňok, Siwek, 2001). W czeskiej części Śląska Cieszyńskiego 86,9\% respondentów uznało, że ich gmina zamieszkania należy do Śląska, podczas gdy na Śląsku Opawskim 72,2\% ankietowanych miało podobną opinię. Jak zauważyli Kaňok i Siwek, poziom deklarowanej przynależności do Śląska spadał w korelacji z kierunkiem południowym i był wyższy w okolicach uprzemysłowionej Karwiny, a niższy w części beskidzkiej, mimo występującego tam żywego folkloru śląskiego (Kaňok, Siwek, 2001). Autorzy badań zwrócili też uwagę, że Śląsk Cieszyński w świadomości społecznej przetrwał, ale w uszczuplonej postaci, ulegając rozmyciu zwłaszcza na granicy z Morawami. Z kolei Jakub Grygar na podstawie swoich badań przeprowadzonych w latach 2000-2004 wśród mieszkańców Stonawy (północna część czeskiej części Śląska Cieszyńskiego) wyróżnił następujące kategorie miejscowych identyfikacji: (a) Tustelian — przynajmniej od dwóch pokoleń posługujących się gwarą; (b) Polaków - faktycznie zaliczani do Tustelian - którzy akcentują swój związek z tradycyjną kulturą regionalną, ale uważaną w podobnym stopniu za część szerszej kultury „polskiej”; (c) Ślązaków (Ślónzoków) zaliczanych do kategorii Tustelian - którzy z powodów swoich doświadczeń historycznych „rezygnują z możliwości bezproblemowego określenia się jako Czesi albo Polacy" (Grygar, 2008, s. 81); (d) Czechów — którzy do Stonawy przybyli najczęściej w poszukiwaniu pracy w kopalniach (Grygar, 2008).

Specyficzne położenie Śląska Cieszyńskiego — od 1920 roku po obu stronach granicy państwowej - po transformacji polityczno-ustrojowej w Europie Środkowo-Wschodniej na przełomie lat 80. i 90. wpłynęło na intensyfikację kontaktów społeczno-kulturowych między grupami etnicznymi i narodami, a także stało się strefą wielokulturowości lub ścierania się, a nawet walki o dominację którejś z kultur narodowych. Powstały też instytucjonalne płaszczyzny tych kontaktów w formie umowy o transgranicznej współpracy regionalnej (w 1993 roku) i euroregionalnej (od 1998 roku), jak również na poziomie lokalnym (np. wspólna organizacja Święta Trzech Braci w Cieszynie i Czeskim Cieszynie od 1991 roku). Wydaje się jednak, że pomimo poczucia specyficznej śląskości po obu stronach Olzy ukształtowanie się wyraźnej tożsamości o charakterze transgranicznym będzie procesem długotrwałym i natrafiającym na wiele przeszkód. Do takich przeszkód należą wydarzenia tkwiące w pamięci historycznej mieszkańców (Glajcar, Broda, 2008; Studnicki, 2015). Wśród symboli pamięci zbiorowej wyznaczających współczesne na tym pograniczu konflikty Grzegorz Studnicki wymienił m.in. odbudowany w 2008 roku pomnik Ślązaczki (tj. Pomnik Ku Czci Legionistów Śląskich Poległych za Polskę) oraz po czeskiej stronie - płaskorzeźbę pierwszego Prezydenta Czechosłowacji Tomáša G. Masaryka, odsłoniętą w 2010 roku, i obelisk poświęcony generałowi Josefowi Šnejdárkowi na górze Połednia (Studnicki, 2015). O trudnych relacjach pomiędzy różnymi grupami społeczno-etnicznymi na Śląsku Cieszyńskim świad-

74 czą też badania ankietowe wśród młodzieży polskiej w Cieszynie oraz na Zaolziu 
przeprowadzone we wrześniu 1995 roku (Rusek, Werpachowski, 1997). Niemal połowa respondentów z Cieszyna określiła swój stosunek do sąsiadów z Czech jako obojętny (45\%), a $28 \%$ jako raczej negatywny.

\section{Rozterki i konkluzje}

Przeprowadzone rozważania wokół pojmowania zjawiska współczesnego regionalizmu oraz omówienie niektórych badań dotyczących świadomości i tożsamości regionalnej na Śląsku Cieszyńskim skłaniają do sformułowania kilku uwag.

Współczesne studia nad regionalizmem w Polsce skupiają się na badaniu różnych form, jak również przejawów tego zjawiska, ale unikają jego oceny, nie mówiąc już o próbach określenia jego stopniowalności czy natężenia. Kierując się cytatem nowozelandzkiej pisarki Katherine Mansfield: „Gdyby można odróżnić prawdziwą miłość od fałszywej, tak jak odróżnia się grzyby jadalne od muchomorów”4, można stwierdzić, że badacze zagadnień związanych z regionalizmem powinni spróbować odpowiedzieć na pytanie: jak odróżnić regionalizm prawdziwy od tego imitowanego przez różne grupy interesu? Prawelska-Skrzypek i Domański, podsumowując badania ankietowe dotyczące zróżnicowania przestrzennego postrzegania własnego regionu przez mieszkańców Śląska Cieszyńskiego, stwierdzili, iż dowiodły one „bardzo silnego poczucia odrębności regionalnej mieszkańców polskiej części” (Prawelska-Skrzypek, Domański, 1997, s. 51) tego obszaru. Również rozważania przeprowadzone przez Rafała Glajcara i Szymona Brodę o wyznacznikach tożsamości mieszkańców Śląska Cieszyńskiego - takich jak: (a) narodowość, (b) język i mowa, (c) wyznanie, (d) autoidentyfikacja mieszkańców oraz (e) relewantne kulturowo i świadomościowo relacje Cieszyniaków z otoczeniem zewnętrznym - skłoniły autorów do uznania tego obszaru za region „o silnej tożsamości kulturowej" (Glajcar, Broda, 2008, s. 137).

Wydawałoby się, że traktowanie regionu na gruncie geografii jako obiektu niezwykle rozciągliwego przestrzennie wprowadza jedynie zamęt pojęciowy. Jednakże geografia polska podejmowała nieraz dyskurs o ograniczeniu terytorialnym regionalizmu — gdy na gruncie nauk społecznych i humanistycznych przenosi się to zjawisko na skalę lokalną (np. przy analizie działalności towarzystw społeczno-kulturalnym o małym zasięgu, zespołów folklorystycznych czy izb prezentujących lokalną kulturę ludową, zwanych regionalnymi). I tak, np. Roch Sulima uznał lokalizm za formę przezwyciężania ograniczeń ideologii regionalizmu i przejaw nowoczesności (Sulima, 2001). Należy zwrócić uwagę, że w tradycji polskich badań geograficznych jednostki terytorialne odpowiadające wielkościowo powiatom

${ }^{4}$ „If only one could tell true love from false love as on can tell mushrooms from toadstools”. Katherine Manfsield Quotes, www.brainyquote.com/authors/katherine-mansfield-quotes [dostęp: 4.12.2020]. 
traktowano na skali przestrzennej jako subregiony (podregiony); czasem w literaturze krajoznawczej i historycznej określano je mianem „ziemi”, a mikroregiony wielkości gminy uznawano za jednostki lokalne. Pomimo że pojawiały się w geografii postulaty przypisywania zjawiska regionalizmu tylko dużym jednostkom terytorialnym, to jednak wiele badań potwierdza transponowanie studiów nad tym zjawiskiem także na skalę subregionalną. Taką pozycję na tej geograficznej skali zajmuje Śląsk Cieszyński (zwłaszcza że, jak wykazano na podstawie badań, region ten ulega procesowi kurczenia) - stąd tak łatwo można wprowadzać zamienną nazwę Ziemia Cieszyńska. Ważnym zadaniem w wymiarze społecznym i behawioralnym byłoby rozpoznanie natury relacji społecznych i emocjonalnych zachodzących w zbiorowościach subregionalnych i lokalnych, by wskazać ich istotę i występujące między nimi różnice.

Ważnym czynnikiem kształtującym świadomość i tożsamość regionalną Śląska Cieszyńskiego w części polskiej było dziedzictwo historyczne i kulturowe, a tworem przestrzennym, do którego się odnoszą te postawy, jest region historyczny. Dlatego Studnicki stwierdza, że „powstałe obrazy przeszłości [...] prezentowane przez różne środowiska - odmalowują jedyny w swoim rodzaju palimpsestowy obraz Śląska Cieszyńskiego, w którego ramach kryje się wiele warstw - miejscami zakrytych, a miejscami wysuwających się na plan pierwszy, gdzie wspólnota ukrywa odrębność, a tożsamość — różnicę" (Studnicki, 2015, s. 483). Liczne badania ankietowe ujawniły, że w wyobrażeniach mieszkańców Śląska Cieszyńskiego — pod wpływem presji dużych ośrodków miejskich położonych na skraju regionu Ostrawy i Bielska-(Białej) - następuje wyraźne przesunięcie granicy w kierunku Cieszyna (zob. rys. 2). W wyniku tej presji regionalizm Śląska Cieszyńskiego ulega wyraźnemu procesowi kurczenia się w wymiarze terytorialnym i może się przekształcić w zjawisko lokalizmu.

Nową postacią regionalizmu na Śląsku Cieszyńskim może być długotrwały proces budowy tożsamości transgranicznej, której charakter jednak będzie odmienny. Na możliwości budowy tożsamości euroregionalnej zwróciła uwagę m.in. Renata Suchocka, która postulowała spojrzeć na ten proces z perspektywy modelu zaproponowanego przez Antoninę Kłoskowską (Kłoskowska, 1996), opierającego się na emocjonalnym przyswojeniu danej kultury (walencji kulturowej) (Suchocka, 2000). W procesie budowania społecznie konstruowanej nowej tożsamości powinny uczestniczyć różne instytucje lokalne i regionalne.

W badaniach nad regionalizmem ścierają się dwie opcje: (a) rygorystycznego pojmowania tego zjawiska, opartego na tradycji badań, oraz (b) poszerzania znaczenia regionalizmu, które może prowadzić do konstruowania nowych podejść interdyscyplinarnych, ale i ujęć eklektycznych (również sprzecznych koncepcyjnie), skutkujących pewną swawolą konceptualną.

$\mathrm{Na}$ zakończenie można też wyrazić nadzieję, że stwierdzenie Zaryckiego, iż „geografia społeczna bywa nie zawsze udaną próbą uprawiania socjologii” (Zarycki, 1998, s. 173) nie odnosi się do sfery badań nad regionalizmem przez geografię człowieka, a w szczególności geografię społeczną, a wymienione refleksje w tym

76 zakresie mogą o tym świadczyć. 


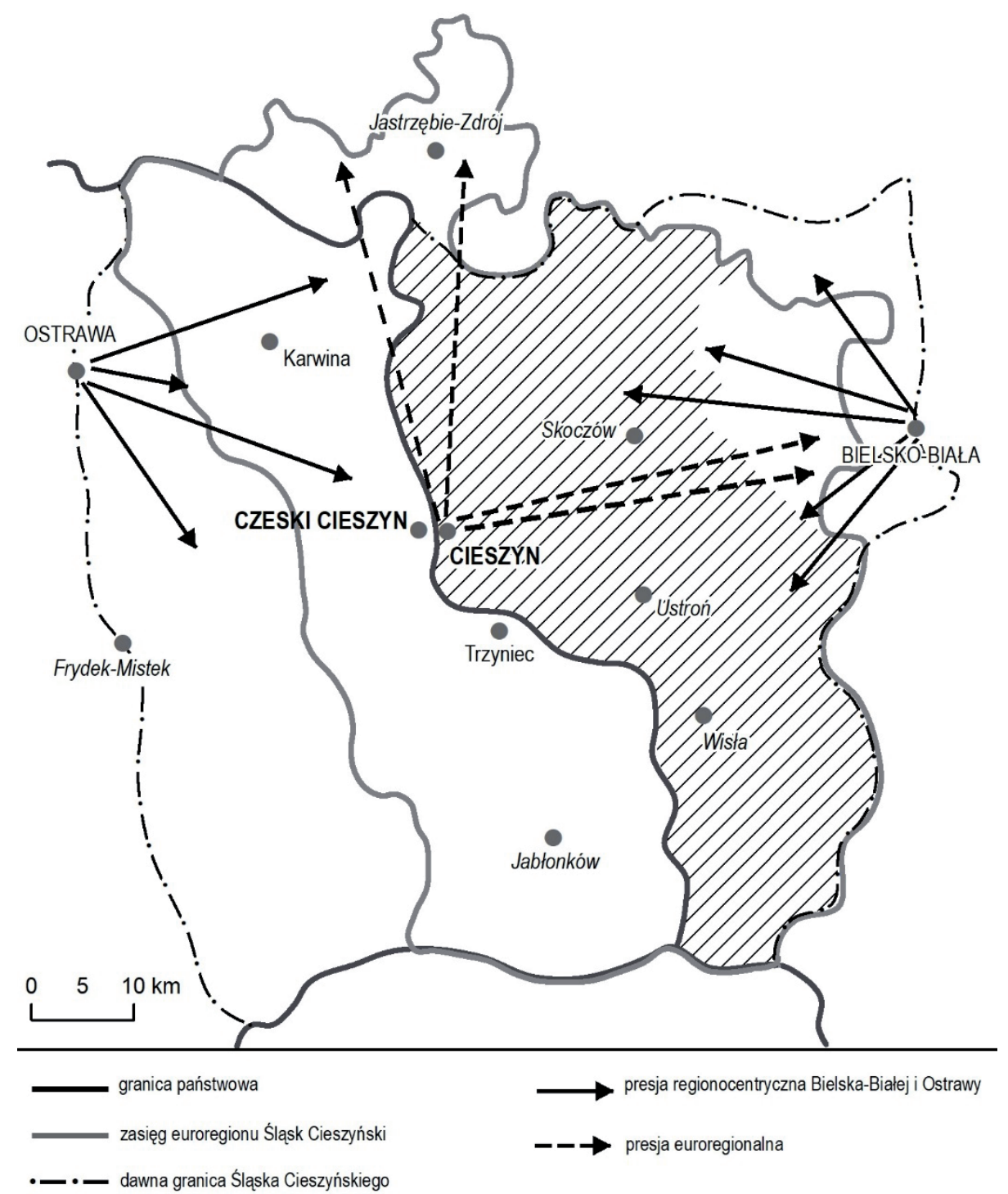

Rys. 2. Struktury terytorialno-organizacyjne (powiat cieszyński, Euroregion) na obszarze Śląska Cieszyńskiego i elementy presji na zmiany tych struktur

Źródło: opracowanie własne na podstawie materiałów informacyjnych Euroregionu Śląsk Cieszyński oraz badań. 


\section{Bibliografia}

Bartnicka M., 1986: Percepcja przestrzeni miejskiej Warszawy - na przykładzie dzielnicy Ochota. „Przegląd Geograficzny”, nr 59, s. 165-190.

Bartnicka M., 1989: Wyobrażenia przestrzeni miejskiej Warszawy. Studium geografii percepcji. „Dokumentacja Geograficzna”, nr 2. Wrocław-Warszawa: Zakład Narodowy im. Ossolińskich, Wydawnictwo Polskiej Akademii Nauk.

Berezowski S., 1963: Nasza ankieta regionalna. „Poznaj Świat”, nr 10, s. 42—43.

Bradshaw M., 1988: Regions and Regionalism in the United States. Jackson-London: University Press of Mississippi.

Brañas A., 1889: El regionalismo: estudio sociológico, histórico y literario. Barcelona: Jaime Molinas.

Chociszewski J., 1892: Podręcznik geografii ojczystéj zawierajacy treściwy opis ziem dawnej Polski z uwzględnieniem dzisiejszych stosunków i podziału politycznego. Dodana krótka wiadomość o Czechach i Rusinach. Poznań: Nakładem K. Kozłowskiego.

Chojnicki Z., 1973: Założenia i perspektywy rozwoju geografii ekonomicznej. „Przegląd Geograficzny", nr 1, s. 3-27.

Chojnicki Z., 1996: Region w ujęciu geograficzno-systemowym. W: Podstawy regionalizacji geograficznej. Red. T. Czyż. Poznań: Bogucki Wydawnictwo Naukowe, s. 7—43.

Chojnicki Z., Czyż T., 1992: Region - regionalizacja — regionalizm. „Ruch Prawniczy, Ekonomiczny i Socjologiczny", nr 2, s. 1-18.

Czerny M., Kaczmarek T., Lisocka-Jaegermann B., Matykowski R., 1999: Region w badaniach geografi społeczno-ekonomicznej. W: Geografia polska u progu III tysiąclecia. T. IV. Red. B. Domański, W. Widacki. Kraków: Instytut Geografii UJ, s. 167-182.

Damrosz J., 1987: Region i regionalizm (studium interdyscyplinarne). Warszawa: Instytut Kultury.

Deas I., 2000: From the "New Localism" to the "New Regionalism"? The Implications of Regional Development Agencies for City-Regional Relations. "Political Geography", Vol. 19, s. 273-292.

Dobrowolski P., 2000: Regionalizm i wspótpraca międzyregionalna na tle europejskich procesów integracyjnych. W: Polityka. Przedmiot badań $i$ formy przejawiania się. Red. P. Dobrowolski, M. Stolarczyk. Katowice: Wydawnictwo Uniwersytetu Śląskiego.

Domański B., Prawelska-Skrzypek G.,1986: Przestrzenne zróżnicowanie wyobrażeń o mieście na przykładzie Jarosławia. „Folia Geographica. Series Geographica Oeconomica", nr 19, s. 131-140.

Dutkowski M., 2008: Mówiąc „region”... W: Region społeczno-ekonomiczny i rozwój regionalny. Red. J.J. Parysek, T. Stryjakiewicz. Poznań: Bogucki Wydawnictwo Naukowe, s. 369-387.

Dylikowa A., 1973: Geografia Polski. Krainy geograficzne. Warszawa: Państwowe Zakłady Wydawnictw Szkolnych.

Eberhardt P., 2006: Twórcy polskiej geopolityki. Kraków: Wydawnictwo Arcana.

Fournier L.S., 2006: Le discours régionaliste en Provence (France). „Journal des Anthropologues", vol. 104-105, s. 247-264.

Gąsior G., 2008: Zaolzie. W: Zaolzie. Polsko-czeski spór o Śląsk Cieszyński 1918-2008. Red. A. Knyt. Warszawa: Ośrodek Karta, s. 2-3. 
Gąsior-Niemiec A., 2010: Dyskurs nowego regionalizmu na przełomie XX i XXI wieku. W: Myśl polityczna w Polsce XX-XXI wieku. Wybrane problemy. Red. H. Cimek. Rzeszów: Wydawnictwo Uniwersytetu Rzeszowskiego, s. 32-63.

Glajcar R., Broda S., 2008: Wyznaczniki tożsamości mieszkańców Śląska Cieszyńskiego. W: Wokót tożsamości regionalnej. Zagłębie Dąbrowskie i jego sąsiedzi. Red. M. Kaczmarczyk, W. Wojtasik. Sosnowiec: Oficyna Wydawnicza Humanitas, s. 127-137.

Golachowski S., 1975: Geografia a socjologia. „Acta Universitatis Wratislaviensis”, r. 237 (Prace Instytutu Geograficznego, ser. B), s. 5-9.

Grigg D., 1967: Regions, Models, and Classes. W: Models in Geography. Eds. R.J. Chorley, P. Haggett. London: Menthuen, s. 461-501.

Grygar J., 2008: Wymiary pamięci i tożsamości mieszkańców czeskiego Śląska Cieszyńskiego. W: Śląsk Cieszyński. Granice - przynależność - tożsamość. Red. J. Spyra. Cieszyn: Muzeum Śląska Cieszyńskiego, s. 73-83.

Handke K., red., 1993: Region, regionalizm - pojęcia i rzeczywistość. Warszawa: Slawistyczny Ośrodek Wydawniczy.

Jałowiecki B., 1996: Przestrzeń historyczna, regionalizm, regionalizacja. W: Oblicza polskich regionów. „Studia Regionalne i Lokalne”, nr 17(50). Red. Idem. Warszawa: UW EIRRiL, s. $19-88$.

James P.E., 1959: American Geography at Mid-Century. W: New Viewpoints in Geography. Ed. Idem. Washington: National Council for the Social Studies.

Janiszewski M., 1959: Regiony geograficzne Polski. Warszawa: Państwowe Zakłady Wydawnictw Szkolnych.

Jordan T.G., Rowntree L., 1979: The Human Mosaic: A Thematic Introduction to Cultural Geography. Michigan: Univrsity of Michigan, Harper \& Row.

Kaňok J., Siwek T., 2001: Czeska część Ślaska Cieszyńskiego w świadomości mieszkańców - mapa mentalna. W: Problemy społeczno-demograficzne pogranicza polsko- czeskiego na przykładzie Śląska Cieszyńskiego. Red. J. Runge, F. Kłosowski. Katowice: Wydawnictwo Uniwersytetu Śląskiego, s. 119—131.

Katherine Manfsield Quotes, www.brainyquote.com/authors/katherine-mansfield-quotes [dostęp: 4.12.2020].

Keating M., 1998: New Regionalism in Western Europe. Cheltenham: E. Elgar.

Kiełczewska-Zaleska M., 1980: O znaczeniu regionów geograficzno-historycznych w geografii regionalnej Polski. „Przegląd Geograficzny”, z. 4, s. 705-714.

Kłoskowska A., 1996: Kultury narodowe u korzeni. Warszawa: Wydawnictwo Naukowe PWN.

Kłosowski F., Runge J., 2001: Wprowadzenie. W: Problemy społeczno-demograficzne pogranicza polsko-czeskiego na przykładzie Śląska Cieszyńskiego. Red. Eidem. Katowice: Wydawnictwo Uniwersytetu Śląskiego, s. 7-12.

Koter M., 1993: Region polityczny — geneza, ewolucja i morfologia. W: Region, regionalizm - pojęcia i rzeczywistość. Red. K. Handke. Warszawa: Slawistyczny Ośrodek Wydawniczy, s. 49-74.

Kowalski M., 2003: Polaryzacja zachowań wyborczych w Polsce jako rezultat cywilizacyjnego rozdarcia kraju. W: Przestrzeń wyborcza Polski. Red. Idem. Warszawa: Polskie Towarzystwo Geograficzne, IGiPZ PAN, s. 11-48.

Kucharska J., 1993: Rola więzi regionalnej w procesie identyfikacji etnicznej ludności kaszubskiej (studium zmian w samookreśleniu ludności społeczeństw lokalnych). W: Regionalizm jako folkloryzm, ruch społeczny i formuła ideologiczno-polityczna. Red. M. Latoszek. Gdańsk: Gdańskie Towarzystwo Naukowe, s. 87-98. 
Kwaśniewski K., 1993: Regionalizacja i regionalizm a podział administracyjny. W: Regionalizm jako folkloryzm, ruch społeczny i formuła ideologiczno-polityczna. Red. M. Latoszek. Gdańsk: Gdańskie Towarzystwo Naukowe, s. 187-195.

Kwiatkowski P., 1984: Ideologia regionalizmu w Polsce międzywojennej. „Kultura i Społeczeństwo", nr 4, s. 143-156.

Latoszek M., red., 1993: Regionalizm jako folkloryzm, ruch społeczny i formuła ideologiczno-polityczna. Gdańsk: Gdańskie Towarzystwo Naukowe.

Libura H., 1988: Badania wyobrażeń geograficznych na przykładzie mieszkańców Sanoka. „Dokumentacja Geograficzna”, nr 1. Wrocław-Warszawa: Zakład Narodowy im. Ossolińskich, Wydawnictwo Polskiej Akademii Nauk.

Loth J., 1919: Wykład geografji ekonomicznej Ziemi Polski przedrozbiorowej: na podtożu geografji ekonomicznej $i$ antropogeografii z uwzględnieniem historii i towaroznawstwa. Warszawa: Polska Agencja Wydawnicza.

Lynch K., 1960: The Image of the City. Cambridge: MIT Press.

Manikowska B., Matykowski R., 1984: Analiza struktury przestrzennej miasta na podstawie wyobrażeń i ocen jego mieszkańców (na przykładzie Ślesina). „Sprawozdania Komisji Geograficzno-Geologicznej PTPN za rok 1982”, nr 100, s. 111-117.

Matykowski R., 1997: Ślask Cieszyński a Podbeskidzie. Świadomość regionalna mieszkańców województwa bielskiego. W: Ślask Cieszyński i inne pogranicza w badaniach nad tożsamością etniczna, narodowa i regionalną. „Studia Etnologiczne i Antropologiczne”, t. 1. Red. I. Bukowska-Floreńska. Katowice: Wydawnictwo Uniwersytetu Śląskiego, s. 99-114.

Matykowski R., 2003: Teoretyczne podstawy geograficznych badań nad regionalizmem. W: Kulturowy aspekt badań geograficznych. Studia teoretyczne i regionalne. Red. E. Orłowska, J. Klementowski. Wrocław: PTG — Oddział Wrocławski, Instytut Geografii i Rozwoju Regionalnego Uniwersytetu Wrocławskiego, s. 35-49.

Matykowski R., 2006: Regions and Regionalism in Poland. W: Poland in the Geographical Centre of Europe: Political, Social and Economic Consequences. Ed. M. Czerny. New York: Nova Science Publishers, s. 47-70.

Matykowski R., 2017: Zbiorowości społeczno-przestrzenne i ich zwiazki z terytorium. Formy i czynniki regionalizmu w Polsce. Poznań: Bogucki Wydawnictwo Naukowe.

Miszczuk A., 2003: Regionalizacja administracyjna III Rzeczypospolitej. Koncepcje teoretyczne a rzeczywistość. Lublin: Wydawnictwo Uniwersytetu Marii Curie-Skłodowskiej.

Nowak K., 2001: Dzieje Śląska Cieszyńskiego po 1918 roku. W: Śląsk Cieszyński. Środowisko naturalne, zarys dziejów, zarys kultury materialnej i duchowej. Cieszyn: Macierz Ziemi Cieszyńskiej, s. 203-226.

Nowak K., 2008: Od stycznia 1919 do sierpnia 1920. W: Pierwsza Niepodległość. Polacy na Śląsk Cieszyńskim w 1918 roku. Red. Idem. Cieszyn: Biuro Promocji i Informacji Urzędu Miejskiego, s. 102-132.

Ossowski S., 1947: Zagadnienia więzi regionalnej i więzi narodowej na Ślasku Opolskim. „Przegląd Socjologiczny”, t. IX, s. 73-124.

Paasi A., 1986: The Institutionalization of Regions: A Theoretical Framework for Understanding the Emergence of Regions and the Constitution of Regional Identity. "Fennia", Vol. 164, No. 1, s. 105-146.

Panic I., 2001: Ziemia Cieszyńska w czasach piastowskich (X-XVII wiek). W: Ślask Cieszyński. Środowisko naturalne, zarys dziejów, zarys kultury materialnej i duchowej. Cieszyn: Macierz Ziemi Cieszyńskiej, s. 121-144. 
Pawłowski S., 1934: Regionalizm geograficzny i jego rozwój w Polsce. W: Ruch regionalistyczny w Europie. Red. A. Patkowski. Warszawa: Wydawnictwo Sekcji Regjonalistyczno-Krajoznawczej Związku Nauczycielstwa Polskiego, s. 5-20.

Piskozub A., 2002: Polska w Europie regionów. Dziedzictwo tradycji historycznej jako podstawa wspótczesnej tożsamości regionalnej ziem polskich w jednoczącej się Europie. W: Lokalna wspólnota polityczna a zagadnienie tożsamości zbiorowej. Red. R. Piekarski. Kraków: Universitas, s. 159-168.

Podraza A., 2006: Małopolska jako region historyczny. (Rozważania na tle zainteresowań historia regionalna). W: Europa - Galicja — Regiony. Pisma historyczne. Red. A. Podraza, G. Nieć. Kraków: Księgarnia Akademicka, s. 57-78.

Prawelska-Skrzypek G., Domański B., 1997: Zróżnicowanie przestrzenne postrzegania własnego regionu przez mieszkańców Ślaska Cieszyńskiego. W: Śląsk Cieszyński $i$ inne pogranicza $w$ badaniach nad tożsamościa etniczna, narodowa i regionalna. „Studia Etnologiczne i Antropologiczne”, t. 1. Red. I. Bukowska-Floreńska. Katowice: Wydawnictwo Uniwersytetu Śląskiego, s. 42-52.

Prawelska-Skrzypek G., Matykowski R., 2001: Współczesne oblicza regionalizmu: analiza przypadków w Polsce. „Regiony Polski”, nr 2(3), s. 45-73.

Romer E., 1916: Geograficzno-statystyczny atlas Polski. Warszawa-Kraków: Gebethner i Wolff.

Romer E., Weinfeld I., 1917: Rocznik Polski. Tablice statystyczne. Kraków: Nakład Księgarni G. Gebethnera i Spółki.

Rozporządzenie Ministra Nauki i Szkolnictwa Wyższego z dnia 20 września 2018 r. w sprawie dziedzin nauki i dyscyplin naukowych oraz dyscyplin artystycznych. Dz.U. 2018, poz. 1818.

Rubinstein M.J., 2002: The Cultural Landscape: An Introduction to Human Geography. Upper Saddle River: Prentice Hall.

Runge J., 2003: Śląsk Cieszyński jako czesko-polski region przygraniczny. „Regiony Polski”, nr 1(5), s. 139-153.

Rusek H., Werpachowski L., 1997: Wymiary tożsamości regionalnej młodzieży pogranicza polsko-czeskiego. W: Ślask Cieszyński i inne pogranicza w badaniach nad tożsamościa etniczna, narodowa i regionalna. „Studia Etnologiczne i Antropologiczne”, t. 1. Red. I. Bukowska-Floreńska. Katowice: Wydawnictwo Uniwersytetu Śląskiego, s. $28-41$.

Rykiel Z., 1985: Badania świadomości regionalnej - przykład regionu katowickiego. „Przegląd Geograficzny”, z. 1, s. 7-58.

Rykiel Z., 1989a: Niektóre problemy świadomości regionalnej. W: Struktury i procesy społeczno-demograficzne w regionie katowickim. „Prace Geograficzne IGiPZ PAN", nr 151. Red. Idem. Wrocław: Zakład Narodowy im. Ossolińskich, s. 93105.

Rykiel Z., 1989b: Wyobrażenia i stereotypy Ślaska. W: Struktury i procesy społeczno-demograficzne w regionie katowickim. „Prace Geograficzne IGiPZ PAN”, nr 151. Red. Idem. Wrocław: Zakład Narodowy im. Ossolińskich, s. 107-120.

Rykiel Z., 1993: Typologia ruchów regionalnych $w$ Polsce. W: Region, regionalizm - pojęcia i rzeczywistość. Red. K. Handke. Warszawa: Slawistyczny Ośrodek Wydawniczy, s. 87-95.

Rykiel Z., 1999: Regionalizm ekonomiczny a regionalizacja szans rozwojowych $w$ Polsce. W: Przeksztatcenia regionalnych struktur funkcjonalno-przestrzennych. T. IV. Red. J. Łoboda, K. Grykień. Wrocław: MarMar, s. 227-245. 
Rykiel Z., 2000: Globalizacja, unionizacja i regionalizacja polskiej przestrzeni. „Studia Regionalne i Lokalne EIRRiL UW", nr 1(1), s. 36-46.

Rykiel Z., 2001: Krytyka teorii regionu społeczno-ekonomicznego. Białystok: Wydawnictwo WSzFiZ w Białymstoku.

Siwek T., Kulczyńska K., Matykowski R., 2009: Cieszyn i Śląsk Cieszyński a przemiany polityczne na pograniczu Olzy w XX wieku. W: Geografia historyczna jako determinanta rozwoju nauk humanistycznych. Red. M. Kulesza. Legnica-Łódź: Państwowa Wyższa Szkoła Zawodowa im. Witelona, Katedra Geografii Politycznej i Studiów Regionalnych Uniwersytetu Łódzkiego, s. 97-107.

Skorowski H., 1999: Europa regionu. Regionalizm jako kategoria aksjologiczna. Warszawa: Wyd. Fundacji ATK.

Sługocki J., 1990: Zagadnienie regionalizmu i tożsamości regionalnej. Bydgoszcz: Wyższa Szkoła Pedagogiczna w Bydgoszczy.

Snoch B., 1991: Ilustrowany słownik dziejów Śląska. Katowice: Wydawnictwo „Śląsk”.

Sosnowski P., 1918: Geografja Polski w dawnych granicach. Lwów: Książnica Polska.

Sowa K.Z., 2000: Ojczyzna mała, ojczyzna wielka, region. W: Socjologia, społeczeństwo, polityka. Red. Idem. Rzeszów: Wydawnictwo Wyższej Szkoły Pedagogicznej, s. $143-163$.

Sowa K.Z., red., 2000: Socjologia, społeczeństwo, polityka. Rzeszów: Wydawnictwo Wyższej Szkoły Pedagogicznej.

Spyra J., 2001: Śląsk Cieszyński pod rządami Habsburgów (1653-1848). W: Ślask Cieszyński. Środowisko naturalne, zarys dziejów, zarys kultury materialnej i duchowej. Cieszyn: Macierz Ziemi Cieszyńskiej, s. 145-165.

Studnicki G., 2015: Śląsk Cieszyński. Obrazy przeszłości a tożsamość miejsc i ludzi. Katowice: Wydawnictwo Uniwersytetu Śląskiego.

Suchocka R., 2000: Rola euroregionów w procesach kształtowania tożsamości narodowej i ponadnarodowej. W: Euroregiony. Mosty do Europy bez granic. Red. W. Malendowski, M. Szczepaniak. Warszawa: Dom Wydawniczy Elipsa, s. 46-56.

Sulima R., 2001: Małe ojczyzny. W: Idem: Głosy tradycji. Warszawa: Wydawnictwo DiG, s. $129-181$.

Szczepański M.S., Ślęzak-Tazbir W., 2008: WieloPolska regionalna. Region i regionalizm w transformacyjnej Polsce. W: WieloPolska regionalna? Regionalizm w Polsce a polityka strukturalna Unii Europejskiej. Red. K. Bondyra, M.S. Szczepański, P. Śliwa. Poznań: Wydawnictwo Wyższej Szkoły Bankowej w Poznaniu, s. 15—43.

Topolski J., 1969: Pojęcie regionu historycznego. Cechy odrębności historycznej Wielkopolski. W: Dzieje Wielkopolski. T. I. Red. Idem. Poznań: Wydawnictwo Poznańskie.

Wituch T., 2001: Terytoria sporne w Europie po roku 1815. Pułtusk: Wyższa Szkoła Humanistyczna.

Zarycki T., 1998: Geograficzne zmagania z przestrzenia. Przykład geografii wyborczej. W: Przestrzeń w nauce współczesnej. Red. S. Symotiuk, G. Nowak. Lublin: Wydawnictwo Uniwersytetu Marii Curie-Skłodowskiej, s. 169-182.

Zawistowicz-Adamska K., 1976: Granice i horyzonty badań kultury wsi w Polsce. Warszawa: Państwowe Wydawnictwo Naukowe.

Zelinsky W., 1980: North America's Vernacular Regions. „Annnals of the Association of American Geographers", Vol. 70, s. 1-17. 